\title{
PUBLIC PARTICIPATION IN FEDERAL RULEMAKING RELATING TO PUBLIC PROPERTY, LOANS, GRANTS, BENEFTTS, OR CONTRACTS *
}

\section{Arthur Eart Bonfield $\dagger$}

\section{The Problem}

In 1941 the Attorney General's Committee on Administrative Procedure concluded that the rulemaking processes of federal agencies "should be adapted to giving adequate opportunity to all persons affected to present their views, the facts within their knowledge, and the dangers and benefits of alternative courses." 1 The Committee realized that the knowledge of an administrative agency is rarely complete, an administrative agency is not ordinarily a representative body, its deliberations are not usually carried on in public, and its members are not subject to direct political controls in the same way as are legislators. Consequently, public participation "in the rule-making process is essential in order to permit administrative agencies to inform themselves and to afford adequate safeguards to private interests." 2 The message of the Attorney General's Committee is as sensible today as it was when first communicated. Very substantial reasons suggest that the interested public should have an adequate opportunity to contribute to the rulemaking process.

The most obvious reason why such public participation is desirable is that it helps to elicit "the information, facts, and probabilities which are necessary to fair and intelligent action" ${ }^{3}$ by those responsible for promulgating administrative rules. Since an agency's own accumulated knowledge and expertise are rarely sufficient to provide all the needed data upon which rulemaking decisions should be based, agency communication with interested parties on the subject of proposed regulations is essential. Such parties are usually in the best position to

* This Article is based upon a report prepared by the author under the auspices of the Administrative Conference of the United States. The Conference, however, does not in any way approve it or evaluate its content, which is the sole responsibility of the author. A recommendation on this subject made by the Administrative Conference may be found in the appendix to this article.

$\div$ Law School Foundation Professor, University of Iowa. B.A. 1956, Brooklyn College; LI.B. 1960, LL.M. 1961, Yale University. Admitted to practice in Connecticut and Iowa.

1 Final Report of the Attorney General's Committee on Administrative PROCEDURE 102 (1941) [hereinafter cited as ATtORNEY GENERAI's FINAI REPORT].

2 Id. 103, quoted in S. Doc. No. 248, 79th Cong., 2d Sess. 19-20 (1946) [hereinafter cited as S. Doc. No. 248] (justification for enacting $\$ 4$ of Administrative Procedure Act). S. Doc. No. 248 is the official legislative history of the APA and conveniently collects working papers and committee reports.

3 Attorney General's Final Report 102. 
provide much of the specific information necessary for wise rule formulation. An opportunity for interested persons to inform appropriate administrators of facts, views, or arguments that they consider relevant to any proposed rule is, therefore, necessary for the sound operation of government. ${ }^{4}$

Other reasons also dictate our government's need to involve interested parties in the formulation of rules by affording them the opportunities just noted. Thirty years ago it was asserted that "our conception of administrative responsibility is undergoing profound change. The emphasis is shifting; instead of [public] subserviency to arbitrary will [of administrators] we require [administrative] responsiveness to commonly felt needs and wants." ${ }^{-6}$ When interested parties have a chance to communicate facts and opinions bearing on proposed regulations to the appropriate authorities, the latter are likely to become more responsive to the problems of those involved than would otherwise be the case.

Public involvement in the formulation of rules is also an excellent way to implement the ideal of participatory democracy. If we assure interested parties an opportunity to influence the decision-makers by communicating with them, public involvment in the rulemaking process will expand, making the process more representative. Public participation in rulemaking may be particularly helpful when an agency promulgates an unpopular rule. Dissenters may be less likely to sabotage a rule in an active way if they have had an adequate opportunity to present their objections prior to its promulgation. Moreover, the failure of officials to secure views from the relevant public before regulations are issued may result in a lack of administrative preparation for certain problems that could arise from those rules' application, or the community's reaction to them.

Parties affected by administrative rules have a distinct personal interest in how they are made. An adequate opportunity to present relevant information to appropriate officials is one of the most important tools with which individuals can defend themselves against an exercise of rulemaking power that may be detrimental to their interests. Political realities may make legislative modification of unwise regu-

4 Recognition of the value of such public participation in government policy formulation was reflected in the May, 1969, action of the President's Task Force on Oil Import Quota Controls. Although not required to do so, the Task Force decided to assure that all relevant information and opinion on the question of oil import quota controls was before it by inviting interested persons to "submit concise written comments to the task force on whether oil imports should remain subject to reduction and, if so, to what degree and by what means." 34 Fed. Reg. 7264 (1969). The Attorney General's Committee on Administrative Procedure made a similar broad solicitation of views in 1940. Attorney General's Final Report 4-5.

5 Friedrich, Public Policy and the Nature of Administrative Responsibility, in Public Administration and Policy 241 (P. Woll ed. 1966). 
lations hopeless; and the breadth of agency discretion may make judicial assaults unsuccessful. In cases of this sort, an opportunity for affected parties to communicate their views on proposed rules to the appropriate officials may be the only meaningful chance those parties will have to protect their interests against rules they consider unwise.

It should be clear that the public participation in rulemaking under discussion here is only directed at assuring an adequate opportunity for interested persons to communicate their views, information, and the like, to the relevant government officials. There is no intention to transfer the actual decision-making power with respect to rules to the interested public. Meaningful public participation in the formulation of administrative rules does not "in any way affect the authority of the agency or its discretion. All that is required is the giving of . . . an opportunity to interested persons to present their views concerning the proposed rule. The department or agency may give such consideration to the views presented as it deems warranted under the facts." 8

To be meaningful, the opportunity to communicate with respect to proposed rules need not necessarily require oral hearings; indeed, written submissions will usually be adequate. Such an assurance of public participation in rulemaking does require, however, that the public be given timely notice of all proposed rulemaking and that an indication of the subject matter of the rulemaking in question be included. Otherwise, the public participation which results will probably

be diffuse and of little real value either to the participating parties or to the agency . . . . Hence, sound practice dictates that ordinary [notice of such rulemaking and opportunities to participate] be accompanied by tentative drafts of the regulations being considered or by a precise statement of the subjects which it is expected may ultimately be touched.

In addition to general notice of proposed regulations, adequate public participation in the rulemaking process requires that the exact terms of a new rule be published a reasonable time before its effective date. Otherwise, even if the public has participated in the preliminary formulation of a rule, the final details of its exact text may not be known to interested parties until the date of its promulgation as law. A procedure for delayed effectiveness is, therefore, necessary "to correct error or oversight in regulations before, rather than after, they become effective." 8 Such a safeguard procedure will "afford persons affected

6 Commisston on Organization of the Executive Branch of the Government, Task Force Report on Legal Services and Procedure 160 (1955) [hereinafter cited as TASK FORCE REPORT].

7 Attorney General's Final Report 108 (emphasis added).

8 Attorney General's Final Report 114. 
a reasonable time to prepare for the effective date of a rule or rules or to take any other action which the issuance of the rules may prompt." 9

Meaningful public participation in the rulemaking process would also seem to demand recognition of another administrative obligation and private right. Interested parties should be able, on their own motion, to induce a reasoned consideration of the propriety of the issuance, amendment, or repeal of a rule, by those authorized to make and modify rules. Absent this ability of the concerned public, administrators satisfied with the status quo might neglect to reexamine their position in light of any new views or information that becomes available. A right to petition for the issuance, amendment, or repeal of a rule and to receive a reasoned response thereto is not only valuable as a protection for private interests, but is also necessary to assure sound government. It forces agencies to reconsider their position with respect to existing or proposed rules in light of petitioners' objections, therefore making it likely that wiser policies will be pursued with respect to those rules than would otherwise be the case.

At some point, however, requirements of the sort discussed above may directly conflict with other values important to the operation of our polity. More specifically, there is an obvious need to conduct our government efficiently, expeditiously, effectively, and inexpensively. No rulemaking scheme may be considered acceptable unless it fairly reconciles these latter values with the societal interest in maximizing public participation in the development of administrative regulations. Imposition of requirements on the rulemaking process that unduly fetter agency action, or frustrate its purposes, would obviously strike an inadequate balance between the competing values involved. Yet the interest in involving interested parties in rulemaking is not so slight that it should be set aside solely on the basis of minor inconvenience or expense to government.

Section 4 of the Federal Administrative Procedure Act (APA), now 5 U.S.C. $\S 553$, attempts to reconcile this conflict between the need for public participation in rulemaking and the need for efficient, expeditious, effective, and inexpensive government. That provision states:

(a) This section applies, according to the provisions thereof, except to the extent that there is involved-

(1) a military or foreign affairs function of the United States; or

(2) a matter relating to agency management or personnel or to public property, loans, grants, benefits, or contracts.

S. Doc. No. 248, at 201, 259. 
(b) General notice of proposed rule making shall be published in the Federal Register, unless persons subject thereto are named and either personally served or otherwise have actual notice thereof in accordance with law. The notice shall include-

(1) a statement of the time, place, and nature of public rule making proceedings;

(2) reference to the legal authority under which the rule is proposed; and

(3) either the terms or substance of the proposed rule or a description of the subjects and issues involved.

Except when notice or hearing is required by statute, this subsection does not apply

(A) to interpretative rules, general statements of policy, or rules of agency organization, procedure, or practice; or

(B) when the agency for good cause finds (and incorporates the finding and a brief statement of reasons therefore in the rules issued) that notice and public procedure thereon are impracticable, unnecessary, or contrary to the public interest.

(c) After notice required by this section, the agency shall give interested persons an opportunity to participate in the rule making through submission of written data, views, or arguments with or without opportunity for oral presentation. After consideration of the relevant matter presented, the agency shall incorporate in the rules adopted a concise general statement of their basis and purpose. When rules are required by statute to be made on the record after opportunity for an agency hearing, section 556 and 557 of this title apply instead of this subsection.

(d) The required publication or service of a substantive rule shall be made not less than 30 days before its effective date, except-

(1) a substantive rule which grants or recognizes an exemption or relieves a restriction;

(2) interpretative rules and statements of policy; or

(3) as otherwise provided by the agency for good cause found and published with the rule.

(e) Each agency shall give an interested person the right to petition for the issuance, amendment, or repeal of a rule.

Another provision of the APA ${ }^{10}$ states that for these purposes

"rule" means the whole or a part of an agency statement of general or particular applicability and future effect designed

10 Administrative Procedure Act $\$ 2$ (c), 5 U.S.C. § 551(4) (Supp. IV, 1969). On the definition of "rule" see $1 \mathrm{~K}$. Davis, Administrative Law Treatise $\$ 5.02$ (1958). 
to implement, interpret, or prescribe law or policy or describing the organization, procedure, or practice requirements of an agency and includes the approval or prescription for the future of rates, wages, corporate or financial structures or reorganization thereof, prices, facilities, appliances, services or allowances therefor or of valuations, costs, or accounting, or practices bearing on any of the foregoing.

The specific question to be examined here is whether section 553 satisfactorily accommodates the competing interests involved insofar as it unqualifiedly exempts from the required rulemaking procedures of that provision all rulemaking "relating to . . . public property, loans, grants, benefits, or contracts." Because of the strong societal interests in assuring public participation in the rulemaking process, these section 553(a) (2) exemptions may be justified only insofar as they are narrowly tailored to preserve those other societal interests conflicting with the need for public involvement in the process, in a degree related to their comparative importance. That is, exemptions from an obligation imposed on agencies to implement public participation in rulemaking should be countenanced only to the extent to which they are absolutely necessary to preserve other values of equal or greater importance.

The inquiry here is intentionally limited to the section 553 (a) (2) exemptions for "public property, loans, grants, benefits, or contracts." The present study will not consider the merits of any other exemptions contained in section 553. It will not, for example, consider the section 553(b) (A) and section 553(d) (2) exemptions for interpretive rules and statements of policy, the section 553(a) (1) exemptions for "military or foreign affairs function[s]," or the section $553(\mathrm{a})(2)$ exemption for "a matter relating to agency management or personnel."

There are several reasons why this study will not even consider the other section 553(a) exemptions just noted. The latter exemptions involve problems that are distinctly separable from, and more difficult to resolve satisfactorily than, those associated with the former exemptions. The interests underlying the inclusion of the other exemptions in the statute are severable in most respects from the interests said to justify the former. There also seems to be greater demand for abolition of the "public property, loans, grants, benefits, or contracts" exemption than for the other unqualified section 553(a) exemptions. Moreover, there is a greater willingness among the government agencies involved to suffer a modification of these (a) (2) exemptions than the others. Practically speaking, the military, foreign affairs, and agency management exemptions seem to be more impervious to change than the section 553(a)(2) exemptions to be examined here. Lastly, 
the exemptions on which this Article will concentrate can analytically be considered as a unit, separate from the others; and of all the section 553 (a) exemptions, they may do the greatest damage with the least justification.

Of course, other exemptions contained in section 553 will be scrutinized to the extent that this becomes necessary to analyze properly the problem under consideration. The above discussion is in no way meant to suggest that the exemptions for the military, foreign affairs, and agency management functions are unrelated to, or completely separable from, those section 553(a)(2) provisions being examined here. Indeed, if reform is required in this area, it may be difficult in the long run without some modification of all these exemptions. For example, modification or elimination of the contracts exemption in section 553(a) (2), should that prove desirable, would still leave virtually all contracts for military procurement excluded from section 553 under the military functions exemption of subsection (a) (1). And elimination of the public property exemption would still leave rulemaking relating to the largest portion of federal property exempt, because it is owned by the Department of Defense and used in the performance of military functions.

However, an evaluation of the section 553 exemptions may be made most satisfactorily in steps. If the "public property, loans, grants, benefits, or contracts" exemption can be adequately dealt with here, future studies may more easily be able to move on to a dispassionate appraisal of the desirability of the other section 553 exemptions. The current study will, therefore, deal only with these exemptions which will be referred to throughout the remainder of this Article as the section 553(a) (2) or subsection (a) (2) exemptions.

\section{The Requirements of Section 553(b)-(e)}

Subsections (b)-(e) of section 553 attempt to assure that the public has an opportunity to participate meaningfully in the rulemaking process. The provisions of section 553(b) require that an agency contemplating the issuance of a substantive rule ${ }^{11}$ must publish a notice in the Federal Register of the proposed rulemaking indicating the time, place, and nature of the public rulemaking proceeding, and a statement

11 Section 553(b) (A) expressly exempts "interpretive rules, general statements of policy, or rules of agency organization, procedure, or practice" from the notice requirements. See U.S. DEPT. OF JUSTICE, ATTORNEY GENERAL's MANUAL ON THE Administrative Procedure Act 30 (1947) [hereinafter cited as Attorney Generac's MANUAL], stating that this restricts the application of the notice and participation requirements in what is now $\$ \$ 533$ (b) -(c) "to substantive rules issued pursuant to statutory authority" (citing a portion of the statute's legislative history, S. Doc. No. 248 , at 19 ). 
of the specific legal authority under which the rule is proposed. ${ }^{12}$ In addition, the agency must include either the actual provisions of the proposed rule, or a summary statement of the subjects or issues to which they relate. The notice involved "must be sufficient to fairly apprise interested parties of the issues involved, so that they may present responsive data or argument relating thereto" as they are entitled to do under the following subsection of section $553 .{ }^{13}$ The agency has the option of dispensing with such publication in the Federal Register only if the notice requirement described above is functionally satisfied because all "persons subject thereto are named and either personally served or otherwise have actual notice thereof in accordance with law."

After giving notice, agencies are required by section $553(\mathrm{c})$ to accord interested persons a chance to participate in the particular rulemaking involved "through submission of written data, views, or arguments with or without opportunity for oral presentation." In practice, the precise procedure actually utilized

may take a variety of forms: informal hearings (with or without a stenographic transcript), conferences, consultation with industry committees, submission of written views, or any combination of these. . . . In each case, the selection of the procedure to be followed will depend largely upon the nature of the rules involved. The objective should be to assure informed administrative action and adequate protection to private interests. ${ }^{14}$

It must be reiterated, however, that according to the statute, interested persons must at the very minimum be afforded an opportunity to submit "written data, views, or arguments with or without opportunity for oral presentation." 15

An agency must review the materials presented to it in the course of such public rulemaking proceedings and include in any rules result-

12 The House Report on the APA stated that "[t] he required specification of legal authority must be done with particularity. Statements of issues in the general statutory language of legislative delegations of authority to the agency would not be a compliance with the section." S. Doc. No. 248, at 258.

13 S. Doc. No. 248, at 200, 258. See also California Citizens Band Ass'n. v. United States, 375 F.2d 43, 48-49 (9th Cir. 1967), stating that the section requiring that notice be given concerning contents of proposed rules of the administrative agency "does not require an agency to publish in advance every precise proposal which it may uitimately adopt as a rule. . . A notice of rulemaking is sufficient if it provides a description of subjects and issues involved."

14 Attorney Generai's Manual 31. The legislative history clearly indicates that $\S 553$ (c) "leaves agencies free to choose from the several common types of informal public rule making procedures, the simplest of which is to permit interested persons to submit written views or data . . . S. Doc. No. 248, at 19.

15 S. Doc. No. 248 , at $200,259$. 
ing from this process a statement of their basis and purpose. ${ }^{16}$ Nevertheless, it is clear that the statute "does not require the formulation of rules upon the exclusive basis of any 'record' made in informal rulemaking proceedings." 17 However, where statutes require a particular kind of rule to "be made on the record after an opportunity for an agency hearing" other provisions of the Administrative Procedure Act outlining more formal hearing requirements will govern that proceeding instead of these informal section 553 provisions; ${ }^{18}$ and in such a case, the rule must be made on the formal "record" so adduced.

Neither the advance notice nor public participation requirements outlined above apply in those cases where "the agency for good cause finds (and incorporates the finding and a brief statement of the reasons therefor in the rules issued) that notice and public procedure thereon are impracticable, unnecessary, or contrary to the public interest." The provision just quoted will be discussed in more detail later in this Article.

Two other subsections of section 553 impose conditions with respect to rules and rulemaking that are operative even if the notice and public participation requirements of section $553(\mathrm{~b})-(\mathrm{c})$ are not applicable because they come within the "good cause" exception just noted. Section 553(e) insists that every agency give interested persons "the right to petition for the issuance, amendment, or repeal of a rule." The mere filing of such a petition does not, however, require an agency to engage in a public rulemaking proceeding on that subject. ${ }^{10}$ The agency must act on the petition in accordance with its procedures promulgated under other provisions of the $\mathrm{APA},{ }^{20}$ and may grant such a petition, undertake public rulemaking proceedings in relation to it, or deny the petition. The chief practical significance of this express right to petition requirement seems to be that the denial of a section 553(e) petition is governed by the provisions of section $555(\mathrm{e})$, which require a prompt notice of the denial "accompanied by a brief statement of the grounds ...." 21

16 "The agency must analyze and consider all relevant matter presented. The required statement of rules issued should not only relate to the data so presented but with reasonable fullness explain the actual basis and objectives of the rule." Id. at $201,259$.

17 Attorney General's Manual 31 (citing Hearings on S. 674, S. 675 and S. 918 Before a Subcomm. of the Senate Comm. on the Judiciary, 77th Cong., 1st Sess., ser. 1, pt. 3, at 444 (1941) [hereinafter cited as 1941 Hearings], which is limited authority for the otherwise sound concluson of the MANUAL on this point because the testimony referred to is that of only a single person, Commissioner C. B. Aitchison of the ICC).

185 U.S.C. \$§ 556-557 (Supp. IV, 1969).

19 Attorney General's Manual 38; S. Doc. No. 248, at 201, 260.

205 U.S.C. $\$ \S 552$ (a) (1) (B)-(C) (Supp. IV, 1969); S. Doc. No. 248, at 260.

21 Attorney General's Manual 39 (citing S. Doc. No. 248, at 201, 260). 
A further requirement may be found in section 553 (d) relating to the time period that agencies must allow between the promulgation of a substantive rule and its effective date. It states that the required publication of a substantive rule under section 552, the freedom of information provision of the Act, must be made at least thirty days prior to the effective date. ${ }^{22}$ The thirty day notice provision, like the right to petition an agency for the issuance, amendment, or repeal of a rule, is applicable even if the public rulemaking procedures of section 553 (b)-(c) are not, because they are found to be "impracticable, unnecessary, or contrary to the public interest." 23 Exceptions are provided to this last noted time requirement, however, in those situations where the substantive rule "grants or recognizes an exemption or relieves a restriction." An exemption is also provided where the agency decides, "for good cause found and published with the rule," that such a minimum thirty day period between the time of a rule's publication and its taking effect is unnecessary. This last exemption will also be discussed in more detail later in the Article.

\section{Section 553(b)-(e) in Relation to the Subsection (a) ExEMptions}

The exemptions contained in section 553(a) for rulemaking involving "a military or foreign affairs function," rulemaking "relating to agency management or personnel," and rulemaking relating to "public property, loans, grants, benefits, or contracts" operate to exclude entirely, and without qualification, all rulemaking in these categories from every provision of subsections $553(\mathrm{~b})-(\mathrm{e})$. Consequently, none of the requirements imposed on administrative agencies by the provisions previously discussed are applicable to these specifically exempted classes of rulemaking. This means, for example, that unless some other statute specifically directs the contrary, ${ }^{24}$ agencies making rules relating

22 See Attorney General's Manual 36, stating that " $t]$ he discussion on section ... [553(d)] in the reports of both the Senate and House Committees on the Judiciary makes clear that the phrase 'The required publication or service of any substantive rule' does not relate back or refer to the publication of general notice of proposed rulemaking required by $[\$ 553(\mathrm{~b})]$; rather it is a requirement that substantive rules which must be published in the Federal Register [see $\$ 553$ (a) (1) (D)] shall be so published at least thirty days prior to their effective date." The language of $\$ 553(\mathrm{c})$ does, of course, lend itself more readily to the opposite construction, but it seems to have been construed only in the manner suggested by the ATTORNEY GENERAL's Manual. See also Lansden v. Hart, 168 F.2d 409 (7th Cir. 1948) ; TASK ForCe REPORT 160. The legislative history referred to may be found in S. Doc. No. 248, at $201,259$.

23 S. Doc. No. 248, at 200-01, 259.

24 Another statute will control if it directs that certain kinds of rules relating, for example, to loans, grants, or benefits be made in accordance with the requirements of $\$ \$ 53$ (b)-(e). See 5 U.S.C. $\$ 559$ (Supp. IV, 1969). The following statement 
to "public property, loans, grants, benefits, or contracts" are never, under any circumstances, obliged as a matter of law to do any of the following things: (1) publish notice of proposed rulemaking in the Federal Register according to specifications of section $553(\mathrm{~b})$; (2) give interested people a chance to participate in the formulation of rules through submission of views or data, according to the terms of section 553 (c) ; (3) give interested persons "the right to petition for issuance, amendment, or repeal of a rule," according to the terms of section 553 (e) ; or (4) publish substantive rules at least thirty days before their effective date as required by section $553(\mathrm{~d}) .^{25}$ The blanket language of section 553(a) makes no allowance whatsoever for the possibility that certain rulemaking within its terms may need to be exempted from some of the subsection (b)-(e) requirements and not from others. Similarly, this provision does not recognize that certain rulemaking within its terms may need exemption from all of those requirements and other such rulemaking from none of them.

The exemptions currently found in section 553(a) obviously proceed upon the assumption that a sweeping judgment can be made concerning those categories of subjects. The policies favoring public participation in rulemaking are outweighed by the consequences of subjecting these particular classes of rulemaking to the requirements of subsections (b)-(e), or the consequences of utilizing a more flexible approach to determine whether, in any given case, they should be subjected to those requirements. The validity of this assumption must be carefully examined and tested with respect to the exemptions for "public property, loans, grants, benefits, or contracts."

It should be stressed that in those cases where rulemaking is excepted from the requirements of section 553 by subsection (a), agencies may use any rulemaking procedure they please, with or without public participation, unless another statute specifies the contrary. The legislative history of the Administrative Procedure Act clearly indicates, however, that none of the blanket introductory exceptions from the section "is to be taken as encouraging agencies not to adopt voluntary public rule making procedures where useful to the agency or beneficial to the public. The exceptions merely confer a complete discretion upon agencies to decide what, if any, public rule making procedures they will adopt in a given situation within their terms." ${ }^{26}$

However, the fact is that most agencies do not usually exercise their discretion to follow the requirements of section $553(\mathrm{~b})-(\mathrm{e})$ when

made during the Congressional hearings on the APA supports this conclusion: "These exceptions would not, of course, relieve any agency from requirements imposed by other statutes." S. Doc. No. 248, at 199.

25 Attorney General's Manual 39; S. Doc. No. 248, at 199, 257.

26 S. Doc. No. 248 , at $199,257$. 
they are not bound to do so. Consider agency practice with respect to that rulemaking of primary concern here-rulemaking relating to "public property, loans, grants, benefits, or contracts." A survey prepared for this study, and distributed under the auspices of the Rulemaking Committee of the Administrative Conference of the United States during the summer of 1969, asked each federal agency:

Does your department or agency follow the procedures specified by $\S 553(\mathrm{~b})$-(e) for any rulemaking exempted from those provisions by $\S 553(\mathrm{a})(1)-(2)$ ? If it does, list the particular kinds of rulemaking exempted by $\S 553$ (a) (1)-(2) for which your department or agency has voluntarily chosen to follow some or all of the procedures specified by $\S 553(\mathrm{~b})-(\mathrm{e})$. Explain. Also list the frequency with which it voluntarily follows those requirements for such exempted rulemaking, and the specific circumstances under which it does so.

Responses to this question by those agencies reporting that they make rules relating to "public property, loans, grants, benefits, or contracts" 27 indicate a pattern. Rulemaking excluded by this part of subsection (a) (2) from the mandatory terms of section 553(b)-(e) usually will not be conducted according to those procedures. That is, most responding agencies indicated that they do not normally follow the provisions of section $553(\mathrm{~b})-(\mathrm{e})$ when their rulemaking is excepted from them by subsection (a) (2)..$^{28}$ And while a number of agencies indicated that they engaged in a contrary practice with respect to such rulemaking, most of these admitted to some inconsistency in this regard. ${ }^{29}$

27 The following agencies responded to the survey questionnaire prior to September 8,1969 , and indicated that they made rules relating to "public property, loans, grants, benefits, or contracts": Department of the Treasury; Small Business Administration; Department of Agriculture; Department of Defense; Veterans' Administration; Post Office Department; Department of Commerce; Atomic Energy Commission; Department of Transportation; Department of Labor; the Department of Health, Education and Welfare; Office of Economic Opportunity; and the National Aeronautics and Space Administration. It is the responses of the above agencies that will be discussed in this study [hereinafter cited as 1969 Survey].

28 See, e.g., the following responses to the 1969 Survey question. The Atomic Energy Commission reported that "The A.E.C. does not follow the procedures specified by 5 U.S.C. $553(\mathrm{~b})-(\mathrm{e})$ for the rulemaking . . . which is exempted from such procedures." The Small Business Administration reported that "S.B.A. does not, as a general rule, follow the requirements of notice of proposed rulemaking and public participation for programs exempt from section 553, although some qualifying comment may be appropriate." The Department of Health, Education and Welfare reported that "the Department has followed the procedures specified by 5 U.S.C. $553(\mathrm{~b})-(\mathrm{e})$ for rulemaking exempted from those provisions by $\$ 553$ (a) (2), on occasion. . ." The Department of Defense and the Veterans' Administration answered "No," and the Department of Agriculture's various divisions indicated that they rarely, if ever, followed usual $\$ \$ 553(\mathrm{~b})-(\mathrm{e})$ procedures in cases of rulemaking exempted by $\$ 553(\mathrm{a})(2)$.

29 See, e.g., the following responses to the 1969 Survey question. The Post Office Department stated that "The Department normally follows the procedures of sec. $553(\mathrm{~b})-(\mathrm{e})$ for any rulemaking leading to the adoption of regulations relating to 
Not only do agencies generally fail to follow the procedures of section 553(b)-(e) in most cases where they are not required to do so, but the public rulemaking procedures actually utilized by administrators in the excepted situations are frequently inadequate substitutes for those found in section $553(\mathrm{~b})-(\mathrm{e}) .^{30}$ The survey prepared for this study asked reporting agencies:

What rulemaking procedures does your department or agency use in those cases where its rulemaking is exempted by $\S 553(\mathrm{a})(1)-(2)$ from the requirements of $\S 553(\mathrm{~b})-(\mathrm{e})$ and it does not choose, in its discretion, to follow \$553(b)-(e)? $\mathrm{Be}$ as specific as possible. Include a concrete example of each of the different kinds of rulemaking procedures utilized by your department or agency when it does not follow $\S 553(\mathrm{~b})-(\mathrm{e})$ because the rulemaking involved is exempted by $\S 553(\mathrm{~b})(1)-(2)$.

Responses indicate that substitute procedures are not always consistent and do not, in many cases, assure adequate notice to affected parties and a sufficient opportunity for their participation. In some cases, the agencies may simply determine the rule they think appropriate and promulgate it, without first notifying or consulting with anyone outside the Government. In other such cases, agencies give notice to, and engage in informal consultation with, whomever they happen to think appropriate under the circumstances. ${ }^{31}$ The actual procedures utilized

domestic mail service when it is considered that the regulation may have a substantial or adverse effect on the public . . . B By way of illustration it was undertaken on twelve occasions during 1968." However, much rulemaking relating to Post Office contracts and the management of Post Office property seems not to be subjected to usual $\$ 553$ requirements. The Department of Transportation stated that "With respect to Parts $151,153,155,159,165,167$, and 169 of title 14, C.F.R. . . the Department does follow all of the section 553 rulemaking procedures, even though exempted therefrom under 553(a) (2), except for minor or technical amendments." However, this means that it does not follow $\$ 553(\mathrm{~b})-(\mathrm{e})$ with respect to rulemaking relating to other Department programs which it lists as exempted by the $\S 553$ (a) (2) exceptions under study here. The Department of Commerce reported that some of its divisions, like the Office of State Technical Services, usually follow $\$ 553(\mathrm{~b})-(\mathrm{e})$ in cases exempted by subsection (a) (2); while others, like the Domestic and International Business Division, do not. The Department of Labor also indicated that it usually follows $\$ \$ 53(\mathrm{~b})-(\mathrm{e})$ with respect to rulemaking of general applicability.

30 Imposition of the $\$ \S 553(\mathrm{~b})$-(e) requirements on rulemaking currently excluded from the ambit of those provisions by $\S 553$ (a) (2) has been opposed by some agencies on the grounds that it is unnecessary as applied to them. They maintain that substitute procedures actually utilized assure adequate notice and participation. See, e.g., Hearings on S. 1663 Before the Subcomm. on Administrative Practice and Procedure of the Sentate Comm. on the Judiciary, 88th Cong., 2d Sess. 20-22 (General Services Administration) and 494-95 (Dept. of Defense) (1964) [hereinafter cited as $S .1663$ Hearings]. See also Hearings on S. 518 Before the Subcomm. on Administrative Practice and Procedure of the Senate Comm. on the Judiciary, 90th Cong. 1st Sess. 246, 379 (1967) (Veterans' Administration, Dept. of Interior) [hereinafter cited as $S .518$ Hearings]. These are not, of course, disinterested judgments, and their validity is, therefore, disputable.

31 See, e.g., the following responses to the 1969 Survey question. The Small Business Administration reported that "parts 112 and 113 Nondiscrimination in Financial Assistance Programs of S.B.A., were prepared internally, but cleared with 
in those cases where agencies are not required to follow section 553 because of subsection (a) (2) may, therefore, often result in a failure to invite interested persons to participate in the formulation of a rule. ${ }^{32}$

Some agencies do utilize substitute procedures that in fact assure adequate notice to affected parties, and a sufficient opportunity for their participation. In a number of cases, those substitute procedures have been specially instituted to cure, at least partially, the failure of section 553 to cover rulemaking relating to "public property, loans, grants, benefits, or contracts." Chief among these is a procedure announced by the Bureau of the Budget in Circular No. A-85 on June 28, 1967. This document applies to most "regulations and revisions thereof which implement a Federal Assistance Program that includes among its eligible recipients state or local governments or quasi public agencies." ${ }^{33}$ It provides that an agency shall give the Advisory Council on Intergovernmental Relations (ACIR) a copy of each such proposed regulation at least 45 days before it is to be promulgated. If legal or other circumstances make this impossible, the agency is to advise the ACIR of this fact, and at least provide it with a summary or abstract in lieu of the regulation. ${ }^{34}$ The ACIR is then to transmit copies of such materials to a number of specific state and local govern-

the Department of Justice. . . . Rules setting forth the policies, proceedings, and requirements for loan, procurement, and other assistance programs are also prepared internally. But in many cases the programs will require or be substantially fostered by contribution from non-governmental sources." The Post Office noted that "when statutory procedures are not used the Department develops its regulations through informal discussions with those to be affected, by negotiation, or by internal decisionmaking processes." The Department of Agriculture's Rural Electrification Agency reported that "R.E.A. Bulletins are formulated by staff members responsible for the program aspects involved in the proposed bulletin with final review and approval by an Assistant Administrator, Deputy Administrator, or the Administrator. Within the discretion of R.E.A., drafts of bulletins may be disctussed informally with representatives of borrowers, contractors, engineers, and other parties interested in R.E.A. programs prior to issuance." The Production Stabilization Division of the Department of Agriculture noted that "almost without exception, the final regulation is published in the Federal Register without prior notice. . . " The same Department also stated that new rules "are prepared by the Farmers Home Administration National Office, with the advice and assistance of the Office of the General Counsel of this Department. . . . Field employees are in daily contact with Farmers Home Administration borrowers and other recipients of Farmers Home Administration assistance and are fully cognizant of their needs and views. Field employees are many times called upon to serve on committees or submit their comments in connection with the development or revision of F.H.A. instructions of major significance." See also responses to a somewhat similar survey question supporting the same point in Bonfield, Representation for the Poor in Federal Rulemaking, 67 Micm. L. REv. 511, 547 nn.41 \& 42 (1969) [hereinafter cited as Bonfield].

32 Officials of a number of major organizations purporting to represent some segment of the poor have complained, for example, of inadequate notice with respect to proposed rules of interest to them, and of many agencies' lack of interest in ascertaining their views in relation to rulemaking affecting the poor. A number of federal agencies have also tacitly admitted that current rulemaking procedures utilized in some rulemaking relating to the subjects exempted by $\S 553$ (a) have been inadequate to assure sufficient representation for the poor in federal rulemaking. See Bonfield 518-19.

33 B.O.B. Circular No. A-85, \& 4 (June 28, 1967).

34 Id. $\S 5(\mathrm{a})$. 
ment associations such as the National Governors' Conference, Council of State Governments, and the United States Conference of Mayors, who will then have up to three weeks within which to comment to the federal agency involved on the proposed regulation. ${ }^{35}$

As helpful as $B O B$ Circular $A-85$ may be, it is no substitute for the more broadly applicable requirements of section $553(\mathrm{~b})-(\mathrm{e})$. The protections of the former scheme do not, for example, apply to rulemaking relating to grants made exclusively to private parties or organizations. Moreover, Circular $A-85$ fails to assure a very large number of "interested" or "affected" persons notice of, or an adequate opportunity to participate in, rulemaking of the type covered by that document for two reasons. In the first place, the document assumes that the procedure contained therein will only apply to that rulemaking "significant enough to be put through the consultation arrangements," leaving it to the discretion of the agencies to decide which rulemaking is significant. The $B O B$ effort does not even supply a standard to measure what is to be considered "significant" for this purpose. Secondly, the Circular in question does not assure many interested persons notice and an opportunity to participate in the regulation making within its terms. Rather, it provides notice and a chance to comment only to certain state and local government associations and, through them, to their members. As the ultimate beneficiaries of particular federal programs granting aid to state and local governments, many classes or groups of citizens have a vital interest in regulations relating to these programs. Their interests, on occasion, may be different from, or even in opposition to, the interests of the political heads of state and local governments whose participation in rulemaking is sought to be protected by this scheme. Yet interested citizens are not assured advance notice or an opportunity to participate in such rulemaking relating to federal grants by $B O B$ Circular $A-85$.

In the end, it must be reiterated that the exemption for "public property, loans, grants, benefits, or contracts" results in a situation in which interested persons are frequently denied notice of, and an adequate opportunity to participate in, rulemaking of concern to them. To the extent this occurs in any case without a justification sufficient to warrant that result, it should not be tolerated. As noted previously, the reasons supporting the section 553(b)-(e) requirements for public participation in rulemaking are very compelling. The potential damage to sound government policy formulation and private rights is great in any case where such participation is not assured. The scope and importance of the subsection (a) (2) exemptions, and the reasons advanced for their existence must, therefore, be examined with special care.

$35 I d . \S 5(\mathrm{c})$. 
IV. The Section 553(a)(2) Exemptions: Their

Scope and Practical Importance

\section{A. Generally}

A few general comments should be made about the linguistic form in which the subsection (a) (2) exemptions are cast. By their terms, these exclusions only apply "to the extent that there is involved" rulemaking that is related to "public property, loans, grants, benefits, or contracts." The legislative history emphasizes the "to the extent" language, stating that these exemptions "apply only 'to the extent' that the excepted subject matter is clearly and directly involved." 36 This suggests that where an agency makes some rules coming within the introductory exemptions and some rules that do not, it may ignore the procedures of subsections $553(\mathrm{~b})-(\mathrm{e})$ in the former cases but must follow them in the latter cases. Even a single scheme of proposed regulations must abide by this principle if it is practically divisible into particular provisions which involve excluded functions and ones that do not. In the report of the Senate Committee on the bill that was to become the Administrative Procedure Act, the Committee stated that:

[I] $\mathrm{t}$ has avoided the mistake of attempting to oversimplify the measure. It has therefore not hesitated to state functional classifications and exceptions where those could be rested upon firm grounds. In so doing; it has been the undeviating policy to deal with types of functions as such and in no case with administrative agencies by name. Thus certain war and defense functions are exempted, but not the War or Navy Departments in the performance of their other functions. ${ }^{37}$

Every federal agency is exempted from the usual section 553 requirements to the extent that they perform the listed functions. Drafters of the statute stated that "[w] here one agency has shown that some particular operation should be exempted from any particular requirement, the same function in all agencies has been exempted." 38 Moreover, the purpose or effect of the rules relating to any of the excepted subjects is irrelevant since all such regulation making is excepted from section 553 by subsection (a) (2). Similarly, the type or quantity of public property involved, or the use to which it is put, and the subject or reason for the loans, grants, benefits, or contracts are also immaterial for purposes of this all-encompassing exemption.

36 S. Doc. No. 248, at 257. See also id. 199.

37 Id. 191.

38 Id. 250. 
On the other hand, rulemaking is arguably not exempt under subsection (a) (2) unless it "directly" or "clearly and directly" relates to the excluded subject matter. ${ }^{39}$ This wording suggests that rulemaking only indirectly or tangentially related to the exempted subjects is not to be treated as within the exclusions, and that unclear, close, or doubtful cases should be treated as outside the exemption. Although the lack of the emphatic word "clearly" in the Senate Report somewhat dilutes this argument, there are strong reasons to construe the introductory exceptions narrowly. Most important is the fact that the subsection (a) (2) exclusions are in the form of broad, unqualified exceptions to provisions implementing a very important general governmental policy favoring public participation in rulemaking, and those usually operative provisions individually contain special detailed exemptions for peculiar cases. Moreover, a principal reason for the enactment of the APA was to secure some standardization of administrative procedure..$^{40}$ Exceptions from any of its provisions should, therefore, usually be construed narrowly in order to achieve that result.

Nevertheless, the language of the section 553(a)(2) exemptions is very broad. Not only are the listed subjects that are excluded specified in terms easily susceptible to wide application, but to be exempted the rulemaking in question must only involve "a matter relating to" the specified subjects. An attempt to minimize the significance of the "relating to" language in subsection (a) (2) of the statute can be made by arguing that there is little if any difference between rulemaking where there is "involved" a certain stipulated matter and rulemaking where there is "involved a matter relating to" that stipulated matter. Since there is ordinarily a difference in meaning between these phrases, and the inclusion of the phrase "relating to" in subsection (a) (2) is unnecessary except as a contrast to the subsection in which it is omitted, a conclusion that the usage only constitutes a choice of style and does not affect content seems difficult to accept.

The following discussion will attempt to state the main thrust of each of the section 553(a) (2) exemptions, and provide some illustrative examples of rulemaking they are deemed to exclude. ${ }^{41}$ An assess-

39 Id. 199, 257. "Directly" is the language from the Senate Report on the APA, and "clearly and directly" from the House Report.

40 McFarland, Analysis of the Federal Administrative Procedure Act, in FEDERAL, Administratrve Procedure Act and the Administrative Agencies 22 (G. Warren ed. 1947). See also S. Doc. No. 248, at 187, 249.

41 Data with respect to the way in which administrators actually construe these exemptions in their every day affairs has been obtained from the survey questionnaire distributed as part of this study to all federal agencies. One question asked was:

What rulemaking does your department or agency engage in that is exempted from the requirements of $\$ \S 553(\mathrm{~b})-(\mathrm{e})$ by $\$ \S 553$ (a) (1)-(2) ? Be as specific as possible by listing the particular programs you administer whose rulemaking is exempt, and for each such program the particular part or parts of 
ment will also be made of the importance of the rulemaking excluded by subsection (a) (2) from the usual requirements of section 553 , and the urgency and care with which these exemptions must be examined in order to ascertain whether they are justified.

No attempt will be made in the following discussion to furnish any mutually exclusive definition of each of the several terms "public property, loans, grants, benefits, or contracts" used in section 553 (a) (2). Rather, as noted above, the main thrust of each term as commonly understood in everyday government parlance will be described. There are two reasons why no effort will be made to delineate precisely each term from every other term. First, such an effort seems unnecessary for present purposes. If rulemaking comes within the ambit of any one of these terms, it is exempt from usual rulemaking procedures under subsection (a) (2). Second, five neat and mutually exclusive categories cannot easily be drawn from the above terms. Upon close examination, each of them overlaps at some point with one or more of the other of these exemptions. A particular instance or class of rulemaking may well fit within two, three, or even more of the above categories. Many agencies acknowledged this overlap between the terms "public property, loans, grants, benefits, or contracts" in responses to the survey prepared for this study. A very large number of agencies listed rulemaking which they considered to be exempted from section 553 by subsection (a) (2) as fitting within two or more of the terms listed in that exclusion. ${ }^{42}$

\section{B. Public Property}

Rulemaking involving any "matter relating to . . . public property" is the first section 553 (a) (2) exemption of concern to this study.

$\S \S 553$ (a) (1)-(2) under which it is exempted. Where some rulemaking for a particular program is exempt and some not, indicate which kinds of rulemaking for that program are exempt and which kinds are not. Very briefly describe the purpose of each such exempted or partially-exempted program and provide citations to the statutes under which it is administered.

Most of the illustrations of exempted rulemaking used in the following section are drawn from the responses to this questionnaire.

42 The extent to which the terms used in subsection (a) (2) may overlap can best be understood by the following examples. A loan of federal funds might be deemed to involve "public property" as well as "loans" because the money being loaned is property of the national government. The same may be true of grants of federal monies and benefits paid out of governmental resources. A loan also may be considered within the "contracts" exemption because the government lends money in consideration of the borrower's promise to return it. The same may be said of grants because the United States usually gives them on certain conditions which the grantee accepts when he voluntarily takes and uses the grant. A benefit might also be deemed to fit within the "contracts" exemption as well as that for "benefits" when it is given because of previous financial contributions which were made with the understanding that subsequent benefits would be paid. Similarly, rulemaking relating to "grants" and rulemaking relating to "benefits" may overlap. Aside from any initial difficulties in 
The 1947 Attorney General's Manual on Administrative Procedure stated that this exclusion "embraces rules issued by any agency with respect to real or personal property owned by the United States or by any agency of the United States. . . . The term 'public property' includes property held by the United States in trust or as guardian; e.g., Indian property." 43 The legislative history of the APA directly supports this assumption. ${ }^{44}$ Consequently, the term "public property" would seem to have a broad content, exempting from section 553 rules relating to any form of property held by the United States in almost any capacity.

Although an argument has been made that the "public property" exemption only applies to property held by the United States in a "proprietary" capacity, ${ }^{45}$ such a position has very little to recommend it. Aside from the difficulty in distinguishing a "proprietary" capacity from other capacities because the content of that term is illusory at best, ${ }^{46}$ neither the language nor legislative history of the Act support any such limitation. The little evidence mustered to support this view can be easily explained on grounds other than an intent to achieve that result. ${ }^{47}$

The areas into which it has been argued that the "public property" exemption should reach are considerably more varied than one might expect. For example, a question arose over whether regulations concerning wild birds under the Migratory Bird Treaty Act were subject to what is now section 553; that is, were wild birds "public property" so that regulations relating to them were exempt from the usual rulemaking requirements? After noting that at common law wild animals are the property of the state in which they are found, the Department of Interior in a memorandum opinion stated:

As have been shown, the cases which speak of title to or ownership of wild animals or birds placed the title or

distinguishing those terms, the United States frequently gives grants to the states to finance benefit programs as, for example, in the Aid to Families with Dependent Children Program. Federal rulemaking relating to that program may well relate both to "grants" and "benefits" since the benefits ultimately paid to the recipients under the program may well be considered federal benefits for purposes of $\S 553(a)(2)$.

43 Attorney General's Manual 27.

44 S. Doc. No. 248, at 257.

45 Wheatley, $A$ Study of Administrative Procedures-The Department of Interior, 43 Geo. L.J. 166, 177-80 (1955). The floor manager of the APA in the House stated that "the exemption of proprietary matters is included because in those cases the Government is in the position of an individual citizen and is concerned with its own property, funds, or contracts." S. Doc. No. 248, at 358. See also id. 199 (stating that the $\$ 553(a)(2)$ exemptions deal with "proprietary matters").

46 Proprietary is defined as "held as the property of a private owner; relating or belonging to a proprietor." WEBSTER'S THIRD NEW INTERNATIONAL DICTIONARY 1819 (1966). See also Black's Law Dictionary 1384 (rev. 4th ed. 1968).

47 The legislative history relied on was undoubtedly intended to constitute simply an explanation of why the public property exclusion was included, or to serve as a shorthand means of designating these exclusions, and was in no way intended as a limitation upon them. 
ownership in the states, not in the Federal Government. The exception of "public property" from the purview of [APA] section 4 extends only to property of the United States. Consequently, the exception would not cover rules regulating the taking of wild game on lands other than those of the Government. $^{48}$

The Post Office has also been very much involved with the "public property" exemption. In Doehla Greeting Cards, Inc. v. Summerfield,99 plaintiff challenged an increase in postal rates. One of his grounds for the suit was that the Interstate Commerce Commission had not held a hearing in conformance with usual procedures prior to giving its required consent to the postal rate increase. The court replied that "the hearing provisions of the Administrative Procedure Act . . . $\$ 4$. . do not apply, as mail rates are within the second exception, 'any matter relating to agency management or personnel or to public property, loans, grants, benefits, or contracts." "50 While the court was not clear as to which of the particular exceptions in section 553 (a) (2) applied to the setting of mail rates, it was probably referring to the "public property" exemption. Many cases have suggested that the United States has a "property right" and a "proprietary interest" in the postal service. ${ }^{51}$

The cases which would support such a theory could be distinguished from the present question because they were concerned with the reach of federal power to protect, foster, and regulate the postal system rather than the extent to which postal authorities were exempted from the usual public rulemaking requirements. Nevertheless, distinctions of this kind seem to be considered irrelevant. At the time of the APA's adoption the Assistant Solicitor General of the United States informed the Solicitor of the Post Office Department that:

I have noted the judicial decisions cited in your letter and which emphasize the proprietary interest of the Federal

$48 \mathrm{M}-34864$ to the Director, Fish and Wildlife Service (Feb. 18, 1947), quoted in Wheatley, $A$ Study of Administrative Procedures-The Department of the Interior, 43 GEo. L.J. 166, 177 (1955).

49116 F. Supp. 68 (D.D.C. 1953).

$50 I d .75$.

${ }^{51}$ See generally Delany, The Federal Administrative Procedure Act and the Post Office Department, in Federal AdMInISTRATIVE PROCEDURE ACT AND THE ADMINISTRATIVE AGENCIES 200-03 (G. Warren ed. 1947) (citing In re Debs, 158 U.S. 564, 583 (1895)) ; Searight v. Stokes, 44 U.S. (3 How.) 151, 169 (1845); Electric Bond and Share Co. v. S.E.C., 92 F.2d 580 (2d Cir. 1937) ; Boeing Air Transport v. Farley, 75 F.2d 765 (D.C. Cir. 1935); Union Pacific R. Co. v. United States, 219 F. 427 (Sth Cir. 1915); United States v. Atlantic Coast Line R. Co., 215 F. 56 (4th Cir. 1914); Cushman, National Police Power Under the Postal Clause of the Constitution, 4 MrNN. L. REv. 402 (1920); Note, Legislation, the Expanding Postal Power, 38 Colun. L.

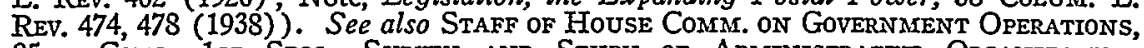
85Th Cong., 1st Sess., Survey and Study of Administratrve Organization, Procenure and Practice in the Federal Agencies 861-63 (Comm. Print 1957) [hereinafter cited as 1957 HousE STUDY]. 
Government in the postal system. It is well known that the United States owns the post office properties and facilities, and that the postal deficits are met by appropriated funds. I concur in your opinion that rules issued by the Postmaster General to prescribe the rates, zones, weight limits, and similar conditions upon which mail service is rendered to the public, involve only matters relating to public property, and are accordingly exempt from the provisions of Section 4 of the Administrative Procedure Act. ${ }^{52}$

Further clarification of the extent of the meaning of "public property" can be gleaned from the Attorney General's Mannal. The Manual states, by way of example, that under the exemption for "public property" rulemaking that relates to

the public domain, i.e., the sale or lease of public lands or of mineral, timber or grazing rights in such lands, is exempt from the requirements of section 4 . The exemption extends, for example, to rules issued by the Tennessee Valley Authority in relation to the management of its properties, and by the Maritime Commission with respect to ships owned by the United States. ${ }^{53}$

Some other examples of rulemaking deemed exempt from section 553 by the "public property" provision include rulemaking undertaken by the General Services Administration relating to the management and use of public buildings, surplus federal property, and stockpiled materials; rulemaking undertaken by the Department of Agriculture relating to the use and disposition of farm surplus commodities and the national forest system lands; rulemaking undertaken by the Department of the Interior relating to the use of the National Parks; and rulemaking undertaken by the Department of Transportation relating to the use and occupancy of the national capital airports.

The subject matter removed from usual rulemaking requirements by this provision is staggering in size both absolutely and in relation to our national resources. Consider the following data with regard to the different types, quantities, and values of federal property, the making of rules in relation to which is excluded from usual requirements for advance notice and public participation. On June 30, 1966, the federal government owned a total of $\$ 347$ billion in real and personal property which was controlled by various agencies. Of this amount, $\$ 102.6$ billion represents the estimated value of real property in the possession of the United States. ${ }^{54}$ Federal land holdings

52 Delany, supra note 51, at 202.

53 Attorney General's Manual 27.

54 Staff of House Comar. on Governanent Operations, 89th Cong., 2D Sess., Federai Real and Personal Property Inventory Report (Civilian and MinItary) of the United States Governasent Covering its Properties Located IN 
amounted to a total of $764,762,000$ acres representing $33.7 \%$ of the total land area of the country. They constituted as high a percentage of total area as $97 \%, 86 \%, 67 \%$, and $64 \%$ in Alaska, Nevada, Utah, and Idaho respectively. ${ }^{\mathbf{5 5}}$ In addition, the federal government owned some 423,634 buildings containing a total of about 2.5 billion square feet of space. ${ }^{56}$ The remaining portion of federal property consisted of personalty holdings of all kinds including machinery and equipment, commodities, materials and supplies, and accounts and loans receivable, which were valued at $\$ 244.4$ billion. Of this, $\$ 3.4$ billion represented the value of commodities for sale by the national government. ${ }^{57}$

The "public property" of the United States can be roughly classified on a functional use basis. The following table shows the primary breakdown on this basis as of June $30,1966 .^{58}$

TABLE A

Functional Use of "Public Property" as of June 30, 1966

National Defense Purposes

International Affairs \& Finance

General Government Purposes

Agriculture \& Agricultural Resources

Commerce and Transportation

Education

Housing \& Community Development

Space Research \& Technology

Veterans' Benefits \& Services

Health, Labor \& Welfare
$\$ 208.5$ billion

26.4 billion

22.6 billion

12.8 billion

11.2 billion

5.7 billion

4.6 billion

3.8 billion

3.4 billion

798.0 million

As the above table clearly indicates, the impact on the daily lives of millions of Americans from regulations governing the management, use, and disposition of these vast governmental assets is enormous.

\section{Loans}

The exemption for rulemaking involving matters relating to "loans" covers a very wide spectrum of government policy-making. The term "loan" covers "something lent for the borrower's temporary use on condition that it or its equivalent be returned." 59 "Loan" covers an "advance of money with an absolute promise to repay," a

the United States as of June 30, 1966, at 11 (Comm. Print 1966) [hereinafter cited as PROPERTY INVENTORY REPORT].

651968 Statistical Abstract of the United States 194 [hereinafter cited as STATISTICAL ABSTRACT].

66 PROperty INVENTORY REPORT 247.

57 Id. 11.

$58 I d .12-13$.

69 Webster's Third New International Dictionary 1326 (1966). 
"[b]ailment without reward, consisting of the delivery of an article by the owner to another person . . . and returned either in specie or in kind," and may either be with or without interest or other similar charge payable to the lender by the borrower. ${ }^{60}$

Two examples of how the "loans" exception would operate in practice will illustrate its breadth. It seems obvious that this exception would make the rulemaking requirements of section 553 inapplicable to the usual functions of government lending agencies, ${ }^{61}$ including their programs which seek to guarantee loans, "since they are matters relating to public loans." 62 Not surprising then is the holding in Barrington Manor Apartments Corp. v. United States. ${ }^{63}$ Plaintiff alleged that a Federal Housing Administration regulation, providing that a one per cent prepayment penalty would be levied on all mortgages held by that agency in cases where they were paid before due, was invalid since it was not adopted in accordance with the rulemaking requirements of section 553 . The court rejected this argument because the lending functions conferred on the FHA by the statute under which the regulation was promulgated were excluded from those requirements by the operation of section $553(\mathrm{a})(2) .^{64}$

Although the above example was a fairly clear case, another illustration demonstrates the extent to which a regulation need only "relate to" loans made by the government to be considered within the subsection (a) (2) exemption. Stroud v. Benson ${ }^{05}$ involved the question whether an order of the Secretary of Agriculture requiring identification of varieties of tobacco on the auction warehouse floor was a rule subject to the procedures of section 553. The Secretary issued an order requiring such identification without prior notice or public participation, on the grounds that it was "a matter relating to" the loan and price support program for tobacco. The court affirmed the Secretary's judgment and justified the relationship because

it has been found as a fact that failure to identify the discount varieties on the warehouse floor has and will tend to depress the tobacco market. A depression of the open market price

60 Black's LAw DictronaRY 1085 (rev. 4th ed. 1968).

61 Reich, Rulemaking Under the Administrative Procedure Act, in FEDERAL ADministrative Procedure Act and the Administrative Agencies 498 (G. Warren ed. 1947).

62 Attorney Generai's Manual, supra note 11, at 27.

63392 F.2d 224 (Ct. Cl. 1968).

64 Id. 227. The court cited Grymes Hill Manor Estates v. United States, 373 F.2d 920, 923 (Ct. Cl. 1967) for the same proposition. That case also held that the function of the F.H.A. pursuant to the statute under which the regulation was promulgated was exempted from the $\$ 553$ requirements by subsection (a) (2). The opinion is not explicit as to which of the (a) (2) exemptions was involved, but it may be implied that the court was referring to the term "loans."

65155 F. Supp. 482 (E.D.N.C. 1957). 
below the level of the support price would ultimately result in the increase of government loans and consequently government loan stocks. The instant order is directly related to this contingency. ${ }^{66}$

This case illustrates the very broad possibilities of an exemption couched in terms of "a matter relating to . . . public . . . loans."

The very great variety and quantity of important government rulemaking activities exempted by the "loans" language from the requirements of section 553 can best be appreciated by enumerating some of those programs to which it applies. The Attorney General's Manual states that this exemption applies to "rules issued with respect to loans by such agencies as the Reconstruction Finance Corporation, the Commodity Credit Corporation, and the Farm Credit Administration. It also exempts rules relating to guarantees of loans, such as are made by the Federal Housing Authority and the Veteran's Administration, since they are matters relating to public loans." 67 Other specific rulemaking deemed exempt from the usual notice and public participation requirements of section 553 because it relates to "loans" includes rulemaking by: (1) the Department of Transportation involving loans to assist financing, acquisition of, or capital improvements to, urban mass transportation systems; (2) the Small Business Administration involving loans to state and local development companies, economic opportunity loans, business loans, and disaster loans; (3) the Department of Health, Education and Welfare involving loans under the National Defense Education Act; (4) the Department of Agriculture relating to loans in the price support programs, loans for rural electric and telephone systems, loans for farm operating needs, farm ownership loans, and soil and water conservation loans; and (5) the Department of Housing and Urban Development relating to loans to finance low and moderate income housing, loans to assist rehabilitation of housing in urban renewal areas, and loans for rental housing for senior citizens. Of course, while the above listing includes some of the more important areas, it is in no way exhaustive for any one agency or all agencies.

To get an idea in economic terms of the size, diversity, and importance of the national government's loan operations, and the extent to which they are a significant factor in our economy and lives, consider the following data. In $1968, \$ 57.2$ billion in direct federal loans and $\$ 108.1$ billion in guaranteed federal loans were outstanding. ${ }^{68}$ The same year, $\$ 25.2$ billion in new direct federal loans and $\$ 21.9$ billion in

68 Id. 490.

67 Atrorney Generax's Manual, supra note 11, at 27.

e8 U.S. Bureau of the Budget, Special ANalysis, Budget of the UNTted States, Fiscal Year 1970, at 62 [hereinafter cited as Speciad Analysis]. 
new guaranteed federal loans were made. ${ }^{69}$ In 1968, the Bureau of the Budget projected that the amount of outstanding guaranteed and insured loans would increase by some $\$ 12.7$ billion in 1969 and by a record $\$ 20.6$ billion in $1970 .^{70}$ By the end of $1970, \$ 190.6$ billion in loans directly made or guaranteed by the United States will be outstanding. ${ }^{71}$ Excluding foreign loans, direct loans made by the United States in 1966 were broken down into the following functional categories and amounts: ${ }^{72}$

\section{TABLE B}

$\begin{array}{lr}\text { Direct Loans by the United } & \text { States in } 1966 \\ \quad \text { Category of Use } & \text { Amount } \\ \text { Agriculture } & \$ 7.9 \text { billion } \\ \text { Education } & 3.1 \text { billion } \\ \text { Homeowners } & 3.0 \text { billion } \\ \text { Industry } & 978.2 \text { million } \\ \text { States, territories, etc. } & 855.8 \text { million } \\ \text { Financial institutions } & 1.9 \text { million } \\ \text { Other loans } & 675.8 \text { million }\end{array}$

In important industries like housing and agriculture federal loans or guarantees of private loans account for an enormous part of the credit available for financing such activities.

The above data make it clear that direct federal loans and federal guarantees of private loans play a very large and vital role in our national government's efforts to (1) improve housing and encourage homeownership, (2) develop agriculture and other natural resources, (3) promote business, especially exports, transportation, and small business generally, (4) redevelop communities and regions, and (5) aid higher education. ${ }^{73}$ Consequently, the section $553(\mathrm{a})(2)$ exemption relating to "loans" excludes from the usual requirements of notice and public participation rulemaking having a vital and enormous impact on the public at large, and specifically bearing on many of the most pressing domestic problems facing our nation.

\section{Grants}

The exemption for rulemaking related to "grants" principally refers to a situation in which the government gives something to a recipient, such as money or land, to enable him to do a particular thing. The main thrust of the "grants" exclusion is toward cases where the United States makes a gift of property on the condition that the re-

$69 \mathrm{Id} .57$.

70 Id. 63.

71 Id. 61.

72 Property Inventory Report 19.

73 Special Analysis 54. 
cipient use it or its proceeds to achieve a specific object. As used in section 553(a)(2), "grants" covers all "subsidy programs" and "grants-in-aid programs under which the Federal Government makes payments to state and local governments" and private individuals and entities. ${ }^{74}$ The subject or object of the grant and its terms and conditions are irrelevant.

The number of such grant programs is very large and their objects numerous, as the following diverse examples will illustrate. The Department of Labor administers grants seeking to secure vocational rehabilitation for migrant workers, and grants for the administration of unemployment insurance and employment service programs. The operation and construction of ships and dissemination of technological information throughout American business are the subjects of grants by the Department of Commerce. Much highway construction results from grants made by the Department of Transportation. The Department of Agriculture supports through grants such diverse programs as those involving school meals, agricultural conservation, and community water and sewer systems. The Department of Health, Education and Welfare makes various kinds of grants to aid the construction and equipment of elementary, secondary, and other educational institutions, as well as to support health related research, the construction of health related facilities, child welfare services, vocational rehabilitation services, and special services for care of the aged and mentally retarded. Among their many grant programs, the Department of Housing and Urban Development makes grants for urban renewal, the Office of Economic Opportunity grants to support legal services for the poor, and the Department of Interior grants to control water pollution.

The enormous significance of the exemption for rulemaking relating to "grants" from the usual requirements of section 553 can be further appreciated by an examination of the extent of our national government's grant programs. Grants-in-aid to state and local governments comprise the overwhelming bulk of federal grants. In 1970 it is estimated that such grants to state and local governments will reach $\$ 24.7$ billion, accounting for $99 \%$ of total federal aid received by those entities in that year. Grants will then account for almost $18 \%$ of state and local revenues, ${ }^{75}$ and an estimated $24 \%$ of federal expenditures on civilian domestic programs. ${ }^{78}$

Functionally speaking, federal grants to state and local governments will break down in the following way during the next fiscal year: agriculture and agricultural resources $4 \%$; natural resources $3 \%$;

74 Attorney General's Mandal, supra note 11, at 27-28.

75 Spectal Analysis 203.

76 Id. 208. 
commerce and transportation $22 \%$; community development and housing $11 \%$; education and manpower $18 \%$; health and welfare $40 \%$; and other $2 \%$. "The cumulative effect of the tremendous increases in human investment grants in the $1960-70$ period will be to place the principal emphasis of federal aid . . . on health and welfare activitiesas well as give added impetus to education and manpower, and community development and housing efforts. In 1970, these programs will account for $69 \%$ of total estimated aid payments." The rising tide of federal grants activities in the areas of human investment can best be depicted by noting that between 1964 and 1970 annual federal grants for health and welfare purposes will rise some $\$ 6.3$ billion or $168 \%$; for education and manpower purposes by $\$ 3.5$ billion or $364 \%$; and for community development and housing purposes by $\$ 2.3$ billion or $546 \% .{ }^{77}$ On the basis of these facts it is clear that rulemaking relating to "grants" by the national government has an enormous and vital effect on the daily lives of tens of millions of Americans.

\section{E. Benefits}

As used in section 553(a)(2) the term "benefits" mainly refers to programs under which the national government makes payments in money or kind to persons in consideration of previous contributions paid to, or in some cases services rendered to, the United States. In a few situations the payments are made merely because of the individual's status. Cash benefits are usually paid from government trust funds, and, unlike grant money, may normally be expended in any way and for any purpose the recipient desires.

The "benefits" exclusion has a very broad scope and has been deemed to cover rulemaking relating to a great variety of programs. More specifically, this exemption applies to rulemaking relating to pensions, medical care, and other similar services provided to veterans by the Veterans' Administration, and to all rulemaking relating to old age, survivors, disability, and health insurance payments made under the Social Security Act. ${ }^{78}$ The exclusion also covers rulemaking relating to the social insurance programs administered for employees of railroads by the Railroad Retirement Board, the social insurance programs for federal employees administered by the Civil Service Commission, and the federal-state unemployment insurance program whose monies are administered by the Department of Labor. Federal rulemaking relating to federally financed, state administered, federal-state assistance programs, such as Aid to Families with Dependent Children, may also be considered covered by this exemption as well as that

78 See Attorney General's Manual, supra note 11 , at 28 
for "grants."

Federal outlays for cash benefit programs totaled $\$ 40$ billion in 1968, an amount equivalent to about five per cent of the Gross National Product. Cash benefits program expenditures are expected to reach about $\$ 49$ billion in 1970 . The total amount spent on cash benefit programs have comprised about one-fourth of all federal expenditures for all purposes in each year since $1961 .^{79}$ Cash benefit programs may be categorized roughly into two groups-one consisting of income replacement benefit programs, and another of income support programs. Some $\$ 42.5$ billion in federal outlays will be made in 1970 for income replacement benefit programs providing protection against loss of earnings due to retirement, disability, death of the breadwinner, and unemployment. Of this amount, about $\$ 36.5$ billion will be from accounts funded in part by employer and/or employee contributions to which over fifty million Americans contribute. In 1969, benefits from the above income replacement programs will be paid to approximately 18 million people. ${ }^{80}$ Federal benefit outlays in the income support programs which base benefits on current needs will amount to $\$ 5.9$ billion by 1970 , and will reach almost 12.4 million recipients. ${ }^{81}$ Aid to Families with Dependent Children is one of the best known of these programs.

The cash benefit programs are administered by a small group of governmental units as the following table will show: ${ }^{82}$

\section{TABLE C \\ Governmental Units Administering the Cash Benefit Programs}

\section{Governmental Unit}

Department of Health, Education \& Welfare Veterans' Administration

Department of Labor

Department of Defense

Civil Service Commission

Railroad Retirement Board
Amount

$\$ 33.3$ billion

5.5 billion

2.9 billion

2.7 billion

2.4 billion

1.6 billion

70 Special ANalysis 174-75. Some of this money, and some of the money in the following figures with regard to "benefits," represents grant payments to the states for benefit programs they will administer. Consequently those funds might better be viewed as "grants" rather than "benefits," even though they may result in the payment of federally financed benefits. However, the overwhelming bulk of the money referred to in the accompanying figures are benefit payments made directly by the United States. See id. 187 ( $\mathrm{HEW}$ "Public Assistance" category).

80 Id. 175, 179-80; Statistical Abstract 476. The survivors and disability programs in this category will benefit some 7.8 million beneficiaries and 4.9 million beneficiaries respectively; and unemployment payments will aid about 5.3 million individuals.

81 Special ANalysis 182.

82 Id. 187. 
In addition to all of the above federal benefit programs providing cash benefits which the recipient is free to use as he chooses, outlays in federal programs providing benefits in kind will be in excess of $\$ 5$ billion by $1970,{ }^{83}$ and will provide benefits for many millions of persons. $^{84}$ It is rulemaking related to these programs, involving billions of dollars and directly affecting tens of millions of Americans, that is removed from the mandatory notice and public participation requirement of section 553 by the term "benefits" in subsection (a) (2).

\section{F. Contracts}

The last section 553(a) (2) exemption to be considered is that for "public . . . contracts." The main thrust of the "contracts" exemption seems to be toward government procurement of real or personal property and services. The legislative history of the Act does cast some doubt as to whether "rulemaking relating to public . . . contracts" includes one area, vitally important to a great many peoplethat of "minimum wage determinations of the Department of Labor in connection with public contracts." ${ }^{85}$ However, in light of all the evidence and the unqualified sweeping language of the exemption those determinations must be deemed within that exclusion. ${ }^{86}$ In this connection it should be noted that the Attorney General's Manual unequivocally states that "the exemption extends to wage determinations made by the Labor Department under the Davis Bacon Act and the Walsh Healy Act, as conditions to construction and procurement contracts entered into by the Federal Government." 87

The "contracts" exemption clearly has a very wide scope. In addition to General Services Administration rulemaking relating to contracts for the procurement of land, goods, and services, and to construction contracts of all kinds, the exemption applies, as do all of the other (a) (2) exemptions, to rulemaking of that sort by every federal

83 Id. 186.

84 Id. 185.

85 Objections were made to an early draft version of the APA which exempted "any matter relating to . . public property or contracts" on the grounds that the $\$ 4$ rulemaking procedures "should not be applied to minimum wage determinations of the Department of Labor in connection with public contracts." The reaction to the criticism was to suggest that the exemption now found in $\$ 553(\mathrm{~b})(\mathrm{B})$ for situations in which the usual procedures are "impracticable, unnecessary, or contrary to the public interest," "amply provide[s] for proper exemptions," rather than to state what otherwise would seem obvious: the term "contracts" completely and unqualifiedly exempted Department of Labor wage determinations from $\$ 4$. S. Doc. No. 248, supra note 2 , at 18 .

${ }^{86}$ See Attorney General's Manual 28, quoted in text accompanying note 87 infra; Reich, supra note 61 , at 498 . Note also that the continuous practice of the Department has been to treat such determinations as exempt. 1969 Survey, supra note 27 (response of the Department of Labor).

87 ATTORNEY GENERAI's MANUAL, supra note 11, at 28 (citations omitted) (citing Perkins v. Lukens Steel Co., 310 U.S. 113 (1940)). 
agency. For instance, it extends to rulemaking by the Treasury Department relating to the terms under which government securities are issued, owned and redeemed "since securities are government contracts." 88 It also extends to regulation making for Department of Agriculture programs such as the Cropland Adjustment Program, Feed Grain Program, Cropland Conversion Program, Soil Bank Program, Wheat Diversion Program, Crop Insurance Program, and a number of Commodity Credit Corporation programs. In addition, it applies to such Health, Education and Welfare contracts as those to establish or expand law school clinical experience programs, and those for university research on a huge number of topics. It also, of course, applies to rulemaking relating to the nondiscrimination in government contracts program administered by the Department of Labor.

An idea of the significance and importance of such government contracts, rulemaking relating to which is excluded by section 553 (a) (2) from the usual rulemaking requirements, may be gained from the following illustrative data. The jobs of millions of Americans are directly and indirectly affected by the contracting activities of the federal government. In fiscal 1969 the United States will purchase $\$ 20.6$ billion in nondefense related goods and services. ${ }^{89}$ Outlays under contracts for direct, nondefense related federal public works, which include the design and construction of new structures, major improvements and modifications of existing structures, and in some cases site acquisition, will reach about $\$ 2.5$ billion in $1970 .^{90}$ The total estimated cost at that time for all nonmilitary federal public works in progress, which includes the sum of payments to be made under contracts in process and contracts to be newly initiated, will amount to $\$ 12.5$ billion. ${ }^{91}$

In 1967, awards were made under defense related procurement contracts, including contracts to obtain military supplies, services, or construction of all sorts, amounting to $\$ 44.6$ billion. $^{02}$ For that same year, it was estimated that jobs for 7.4 million workers, comprising about ten per cent of all employees in this country, was generated by Department of Defense contracts. ${ }^{93}$ It should also be noted that arrangements for the financing of the public debt of the United States, which the Treasury treats under the "contracts" exemption, covered $\$ 326$ billion in 1967 . This included $\$ 210$ billion in marketable public

881969 Survey, supra note 27 (response of the Department of the Treasury).

89 U.S. Bureau of the Budget, Budget of rHe United States Government, Fiscal YeAR 1969, at 541.

30 Speclat Analysis 221-22.

91 Id. 226.

92 Statistical Abstract 249.

93 Id. 251. 
issues. ${ }^{94}$ Rulemaking relating to all of the above, affecting the lives of millions of individuals in every part of this country, is removed by the "contracts" exemption from the requirements of subsections (b) $-(e)$.

\section{G. Some Conclusions With Respect to the Scope and Practical Importance of Section 553(a)(2) Exemptions}

Even if they are strictly construed, which they seldom seem to be in practice, the section 553(a)(2) exemptions are extraordinarily broad and of very great significance. The language of these exemptions excludes an enormous quantity of rulemaking from the requirements of section 553. The classes of rulemaking excluded by it are also of especially great qualitative importance to certain segments of our society and to the public interest at large. ${ }^{95}$ The rulemaking involved has a great impact on our national effort to cure the pressing human problems of the last half of the twentieth century. Most rulemaking excluded from section 553 by subsection (a) (2) relates to programs, or functions, or techniques for governing, which have an unusually large impact on the daily lives of tens of millions of Americans. Efforts to solve our urban crisis, racial problems, poverty problems, environmental quality difficulties, and human spirit and character maladjustments have mainly been pursued through the use of "public property, loans, grants, benefits, or contracts."

As a result, most rulemaking attempting to deal with the important domestic problems facing our nation in this era has been conducted without any guarantee that public participation of the kind stipulated by section 553 (b)-(e) will be allowed. As previously noted, the rulemaking procedures actually utilized in the situations currently exempted by section 553(a)(2) are frequently much less effective to secure adequate public participation than those found in section 553(b)-(e). The impact of this situation on the poor, city people, the farmer, and other separable segments of our society is particularly detrimental.

The exemptions under consideration here are especially undesirable because they tend to insulate almost all of the rulemaking of certain specific federal agencies against unwanted public participation. Agencies whose rulemaking is almost entirely insulated against such mandatory public involvement may, as entire governmental entities, completely lose touch with the public they are to serve, and in that situation, the public may lose any day to day ability to influence the operations of

84 Id. 394-95.

95 See Bonfield, supra note 31, at 512-20. 
such agencies. Although this does not always occur, it is nevertheless a grave danger.

Two points deserve reiteration. First, rulemaking of the kind exempted by subsection (a) (2) intimately affects millions of Americans in their daily lives, and is one of the most important and frequently used means by which our national government seeks to solve our pressing social, economic, and environmental problems. As the Senate Committee on Administrative Procedure stated when it recently recommended modification of section 553(a)(2),

[t]he importance of the Government's activity in this area is now enormous, involving, as it does, tens of billions of dollars of expenditures yearly and vast properties. The rules regulating this activity are consequently of vital concern to the public and it is only reasonable that it be informed and allowed to take part when rules relating to public property, loans, grants, benefits, or contracts are made. ${ }^{96}$

Second, the exemption of rulemaking relating to "public property, loans, grants, benefits, or contracts" also creates a special danger that certain important government agencies may, as entities, become out of touch with and unresponsive to public needs. In light of these two points, and the many reasons favoring required opportunities for public participation in rulemaking that were discussed in the introduction to this paper, the reasons assigned to justify these particular exemptions must be examined with extraordinarily great care.

V. Justifications Advanced for the "Public Property, Loans, Grants, Benefits, or Contracts" Exemptions

Arguments advanced to justify the exemption of the so-called "proprietary" activities of government from usual rulemaking procedures range in character. Some are purely theoretical and historical. Others are intensely practical. But they all deserve careful enumeration and evaluation, for only then can it be ascertained whether they are adequate to justify the status quo in light of the competing policies which favor public participation in rulemaking.

The right-privilege distinction furnishes the most frequent justification for the exemption of subsection (a) (2) rulemaking from the procedural requirements of section 553 . The theory is that no member of the public has a "right" to use public property, receive a loan, grant, or benefit from the government, or to make a contract with the government. Rather, these are all "privileges," and if a man does not like the terms on which these privileges are made available to him, he can

${ }^{36}$ S. 518 Hearings, supra note 30 , at 379 . 
simply refuse to accept the privileges and thereby avoid submission to their conditions. Consequently, rulemaking relating to these subjects should be treated differently than rulemaking relating to other government functions. This idea has been expressed in a number of ways.

An official objecting to the legislative imposition of certain procedures on his agency's activities, including rulemaking of the sort involved here, stated that "the parties affected [by the Bureau of Reclamation's activities] . . . voluntarily submit to regulations in order to gain certain privileges." ${ }^{\mathrm{a}}$ "The Department of Commerce thought that following the usual procedures for rulemaking involving the "proprietary functions" appeared to be "unduly burdensome, particularly where the subject matter does not involve a right of the private parties concerned, but rather bestowal upon them of such benefits as loans, grants, etc." 98 Somewhat differently stated-so as to include the idea that a person may avoid complying with subsection (a) (2) rules promulgated in the isolation of government bureaucracy by not dealing with the government- is the version supplied by the General Services Administration a number of years ago:

The rulemaking which is presently subject to section 4 of the Administrative Procedure Act is rulemaking of the true "regulatory" type; i.e., rulemaking that has a direct impact upon industries or the public which have no choice but to be regulated in the public interest. Such rulemaking affects all members of the public who engage in the regulated activity, whether they are dealing with the Government or with other members of the public, while GSA's regulations apply, in general, only to Government agencies and those members of the public who choose to deal with the Government by furnishing supplies or services, leasing space, buying surplus property, etc. Accordingly, since those affected may extricate themselves of their own volition from the impact of GSA regulations by not dealing with the Government, due process does not require such safeguards as are provided in section 4 of the redraft of S. 1663 [which eliminates the subsection (a) (2) exemptions] for their protection. ${ }^{99}$

The "right-privilege," "avoidable conditions" argument is concerned with the relationship between the subject matter of the exempted category and the recipient. Another distinction, this one between the proprietary and nonproprietary functions of the Government, deals more broadly with the nature of the governmental activity

971941 Hearings, supra note 17, at 689 (statement of Commissioner of Reclamation).

98 S. 1663 Hearings, supra note 30 , at 311 .

99 Id. 522. See id. at 427. 
involved; yet it is often used in close conjunction with the "rightprivilege" argument to justify the current subsection (a) (2) exemptions. It is argued that the procedures contained in section 553 should not be applied to rulemaking involving the subjects listed in subsection (a) (2) because when government exercises these functions it is acting in a "proprietary" capacity. ${ }^{100}$ Consequently, in that situation the Government should be treated as if it were a business or private person handling private money or affairs. The floor manager of the APA in the House argued strongly for this interpretation during the debate on that bill. ${ }^{101}$ Public participation in rulemaking relating to these kinds of situations is deemed to be unnecessary since if a businessman were carrying on the same activities, a private person would have no right to participate in his decision-making process. ${ }^{102}$ Furthermore, it has been asserted that "freeing functions of a proprietary nature, in order to improve the position of the Government when it is operating in an area and along lines similar to a business enterprise, reflects the intentional and traditional position of the Congress in this connection." 103

The above arguments should not be sufficient to justify the current section $553(\mathrm{a})(2)$ exemptions. In the first place, the law is currently in the process of reevaluating the "right-privilege," "avoidable conditions" distinction as a ground upon which to base legal judgments regarding the propriety of governmental action. ${ }^{104}$ The notion that a government agency should be free to deal with people in any manner the former pleases when "privileges" are involved—an idea which was never the product of common sense or sound social policy-is fast disappearing both in the law, and in the public mind. Secondly, because many people have come to depend upon such "privileges" as welfare benefits of various kinds, social security and veterans' benefits, government guaranteed home loans, federal contracts, and public recreation facilities, most people now consider them a part of their entitlement. Furthermore, these people have increasingly little choice but to accept such benefits, whether they be called "rights" or "privileges." Realis-

100 Id. 494 (Department of Defense).

101 S. Doc. No. 248, sitpra note 2, at 358.

102 The Department of Defense has stated that "to publish or to admit the public to the formulation of such a policy [regarding pricing and negotiation of contracts] could only put the Government at serious disadvantage in the negotiation of the contracts for which the policy was intended. Certainly there is no comparable disclosure required of private parties to Government contracts, and it would be unthinkable for the Government, in its proprietary capacity, to participate in the formulation of the business policies and practices of the firms with which it deals." 1957 House STuDY, supra note 51, at 278. See also S.518 Hearings, supra note 30 , at 279 (REA).

1031957 House Study, supra note 51, at 1732 (Federal Housing Administration). 104 See, e.g., Reed v. Gardner, 261 F. Supp. 87 (C.D. Cal. 1966); O'Neil, Unconstitutional Conditions: Welfare Benefits With Strings Attached, 54 CALIF. L. REv. 443 (1966); Van Alystyne, The Demise of the Right Privilege Distinction in Constitutional Law, 81 HaRv. L. Rev. 1439 (1968). 
tically, the conditions imposed on recipients of such grants, benefits, or public contracts, for example, frequently cannot be avoided; in the world as it actually is, most people are in no position to refuse the "privilege" to which the strings are attached.

Finally and most important, both the "right-privilege" and the "proprietary-nonproprietary" distinctions are meaningless in this context because they are not tools with which the problem at hand can be realistically analyzed and evaluated. Rather, they are screens which enable the user to avoid the hard work of investigating the real problem involved. To say that public participation is not required in rulemaking relating to "public property, loans, grants, benefits, or contracts" because they involve "privileges" or "proprietary" matters is to declare a result without giving any relevant reason for it. The fact that a certain construction firm has no "right" to contract with the Government, or that when the Government enters into such a contract it is acting in a "proprietary" capacity, or that the firm need not apply for such a "privilege" if it does not like the rules governing those contracts, has little to do with answering the question under examination. Those labels do not help a decision-maker to decide intelligently whether application of section 553 procedures to rulemaking involving "public property, loans, grants, benefits, or contracts" is in fact undesirable. That conclusion can be reached only after a careful examination of the consequences flowing from an application of section 553 procedures to such cases; and it can be justified only if the specific advantages of public participation in those cases are outweighed by the specific disadvantages that would flow from such a requirement.

As previously noted, the sound administration of government demands fully informed decision-makers. Presumably we intend all aspects of governmental activity to be administered wisely including those that can be labeled "proprietary" and those that involve the dispensing of "privileges." Similarly, our dedication to responsible democratic government requires that the rulemaking process be responsive to affected citizens by allowing them to communicate effectively their views to the relevant officials. Here, too, we presumably want citizens to have a chance to protect their interests against administrative action prejudicial to them in any way, whether that prejudice stems from government action involving a "right" or a "privilege," or a "proprietary" or "nonproprietary" matter. If the (a) (2) exemptions are to persist in the face of such important competing public policies, it should be because of some particular undesirable consequences that might flow from their elimination and not because an irrelevant label can be attached to the subjects they embrace. 
Most federal agencies making rules relating to "public property, loans, grants, benefits, or contracts" take the position that the repeal of section 553(a) (2) would somehow harm the performance of their responsibilities. The specific practical justifications offered to support the exemptions in question vary. They have been gathered from various sources, including congressional hearings, a survey prepared for this study, ${ }^{103}$ and a related survey done for the Administrative Conference of the United States in 1968..$^{106}$

The most frequently articulated, practical justification for the subsection (a) (2) exemptions is that their elimination would cause a greatly increased work load resulting in both delay in the performance of the Government's everyday functions and increased costs in carrying on those functions. The spectre of inefficient delays arises from a sense that the bulkiness of the rulemaking task could cause the bureaucracy to bog down if the exemptions were eliminated. The General Services Administration has opined, for example, that "[p] ublic participation [through rulemaking] in the management [of] property and contracts would be so complicated and cumbersome as to seriously impede and delay the efficient and economical conduct of the Government business." ${ }^{107}$ Similarly, "delay in rendering services and administering benefits" was the prediction of the Veterans' Administration if subsection (a)(2) was eliminated. ${ }^{108}$ The Department of Interior has asked, in this regard:

Is the public really better served through the medium of notice of rulemaking and publication in the Federal Register

105 The question asked in this survey was:

From the point of view of your department or agency what disadvantages, if any, do you see in a statute which would eliminate the general exclusions now found in subsections 553 (a) (1)-(2) and thereby make the provisions of subsections $553(\mathrm{~b})-(\mathrm{e})$ applicable to all rulemaking relating to those currently excepted situations? Be as specific as possible, furnishing concrete, detailed examples. Overly general answers will not be particularly helpful. If your answer varies from program to program or from one type of currently excepted rulemaking to another, please specify and explain in detail.

Despite the instructions contained in the last three sentences, most agencies responded with general answers and did not furnish concrete, detailed examples of how the alleged disadvantages arise in practice. The failure to present specific instances may be indicative of the frailty of the many arguments made against modification of $\$ 553(\mathrm{a})(2)$.

108 The question asked in 1968 was:

What disadvantages, if any, do you see in a statute which would eliminate the exclusions now in 5 U.S.C. 553(a) as they may apply to .. . [your programs with a substantial impact on the poor], and thereby would make the provisions of 5 U.S.C. 553 (b) -553 (e) applicable to all rulemaking relating to those programs? (Assume that the several exceptions now in sections 553(b) through (e) would remain unchanged.)

Bonfield, supra note 31 , at 548 .

1071957 House StUDY, supra note 51, at 1579.

1081969 Survey, supra note 27. See also similar comments by the same agency in 1957 HOUSE STUDX, supra note 51, at 2060 and S. 1663 Hearings, supra note 30, at 463 . 
in every instance of the formulation of a statement of policy? What effect would such a requirement have on the operations of a program agency? Do we want to take the chance of subjecting much of the informal policy making that we do today on a daily basis to the potential of interminable delays? Can our programs afford these delays? Even more importantly, will Congress and the public tolerate these delays? We firmly believe that the answer to all of these questions, when carefully analyzed, must be "no"! 109

On the issue of increased operating costs, the Farmers Home Administration has reported, for example, that elimination of these exceptions "would cause a tremendous increase in the volume of work and operating costs" of that agency. ${ }^{110}$ Even an agency seemingly unopposed to the modification of this exemption has noted that such a change "would, of course, substantially increase the cost of government." 111

Elimination of the present exemptions is also deemed undesirable because it would cause adherence to the procedures of section $553(\mathrm{~b})-(\mathrm{e})$ in many cases where the public has little interest in the rulemaking, ${ }^{112}$ or is unlikely to make a significant contribution to it. ${ }^{113}$ It is alleged that frequently a rule being considered in relation to one of the exempted subjects "is so limited in its application or so minimal in its public impact that . . . any solicitation of comment from the public would be completely unjustified." 114

Furthermore, if rulemaking relating to "public property, loans, grants, benefits, or contracts" is subjected to the requirements of section $553(\mathrm{~b})-(\mathrm{e})$, it is feared that the agencies involved in such rulemaking, and those members of the public most directly affected, would be placed in an adversary position, thereby discouraging mutual cooperation toward finding the best solution to common problems.

109 S. 518 Hearings, supra note 30 , at 42.

2101969 Survey, supra note 27 (response of FHA, Department of Agriculture). See also id. (responses of Forest Service and Soil Conservation Service, Department of Agriculture; Atomic Energy Commission (attachment to response) ; Veterans' Administration); S.1663 Hearings, supra note 30, at 144, 427 (Department of Agriculture and General Services Administration).

111 Bonfield, stpra note 31 , at 549 \& $n .47$ (Department of Labor).

112 See 1957 House STUDY, supra note 51, at 551 (Department of Interior, Fish and Wildlife Service).

113 See S. 1663 Hearings, supra note 30, at 177 G (Department of Treasury); 1969 Survey, supra note 27 (response of Small Business Administration).

114 S. 1663 Hearings, supra note 30, at 427 (General Services Administration). On another occasion a representative of the G.S.A. stated that "public advance notice in the Federal Register and public participation in the formulation of these rules is too much, costs too much, takes too much time, for many rules that would not warrant that type of effort." Transcript of the ABA Symposium on S.1336, Washington, D.C. (Dec. 1, 1966) 109. 
The Tennessee Valley Authority has stated, for example, that their operations would be likely to be disrupted by such a polarization. ${ }^{115}$

The agencies also feared that repeal of subsection (a) (2) would remove desirable flexibility in such rulemaking. The Atomic Energy Commission complained in this regard, as an illustration, that if that agency's rulemaking relating to contracts had to comply with section 553, it would "lessen the Commission's flexibility in dealing with the many different kinds of contracting situations which arise." 118 A similar argument is that elimination of these exemptions would discourage agencies from making worthwhile changes in rules because of the more formal and particularized procedures that would be required. The House and Senate Reports on the APA noted that " $[t]$ he exception of proprietary matters [in section 4] is included because the principal considerations in most such cases relate to mechanics and interpretations of policy, and it is deemed wise to encourage and facilitate the issuance of rules [on these excluded subjects] by dispensing with all mandatory procedural requirements." 117

Section 553(a) (2) is also said to be justified on the grounds that without it, there would be uncertainty in some cases whether public rulemaking procedures must be followed, thus causing litigation or encouraging the use of those procedures in situations where they would be unwise. The Department of Defense reported, for example, that the primary disadvantage to that agency of eliminating the broad exclusions in section 553 was "uncertainty," because the extent to which their rulemaking fits under the more limited exemptions found within section 553(b)-(e) was unclear. This "leads the Department of Defense to fear a rash of litigation testing .. . [its] interpretation of these . . . [other exemptions]." 118

The current exemptions are alleged to be necessary for another reason. In some cases, section 553 procedures are said to be an insufficient means by which to assure that the relevant people participate

115 TVA said that procedures similar to those in what is now $\$ 553$ "would place TVA and its distributors in an adversary position where the tendency would be for each distributor to try to gain an advantage in the formulation of the policy rather than working with TVA and other distributors in a mutual effort to find the best possible solution to each problem as it arises." S.1663 Hearings, sipra note 30 at 544. The agency gave a similar response in 1968. See Bonfield, supra note 31, at 549 n.49. See also 1957 House STudy, supra note 51, at 374 (Office of Education, Department of Health, Education and Welfare).

116 S. 518 Hearings, supra note 30, at 119. See also S. 1663 Hearings, supra note 30 , at 544, stating that "a large measure of the success of T.V.A. . . . attained during the past 31 years has been due to its ability to maintain flexibility in its operations. The proposed revision [elimination of $\S 553(\mathrm{a})(2)$ ] would take away this flexibility."; 1957 House STUDY, supra note 51, at 2060 (Veterans' Administration); Bonfield, supra note 31 , at 548 n. 45 .

117 S. Doc. No. 248, supra note 2, at 199, 247.

1181969 Survey, supra note 27 (response of Department of Defense). See also id. (response of REA, Department of Agriculture). 
adequately in rulemaking relating to the exempted subjects. Requiring adherence to those procedures in the subsection (a) (2) situations might, therefore, sometimes force an agency to follow two sets of procedures in order to involve properly the right people. The Office of Economic Opportunity has noted, for instance, that the procedures prescribed in section 553 "would generally prove ineffective in reaching the poor," and that they would have to be supplemented by other, more effective procedures currently being used by OEO. ${ }^{119}$

The difficulty with all of the previous general justifications for the current section 553 (a) (2) exclusions is that they do not distinguish rulemaking relating to these exempted categories as a class from rulemaking already subjected to the requirements of section $553(\mathrm{~b})-(\mathrm{e})$. Every one of the arguments just outlined could also be made with respect to those classes of rulemaking already subjected to the usual rulemaking procedures. The complaint that increased cost, work load, general delay, duplication, and the like will result if the currently excepted rulemaking is required to follow section 553 (b)-(e) could, for example, also be made with respect to the run-of-the-mill regulatory rulemaking which we have already decided should be subjected to those provisions. The argument that required adherence to usual rulemaking procedures in these cases will reduce needed flexibility, cause uncertainty and litigation, be a waste in many cases, and discourage needed changes in rules, could also undoubtedly be used to support the exemption of all the currently included rulemaking. If it was worth risking some of these possible consequences to bring that rulemaking within the procedures contained in the statute, it is also worth risking them to bring the rulemaking under discussion here within those requirements. There is no evidence to support the general assertion that the deleterious consequences flowing from the inclusion of subsection (a) (2) rulemaking within the provisions of section 553 are greater than the similar consequences resulting from the application of that provision to the rulemaking already subject to its terms. Furthermore, experience with the section 553 procedures as applied to other kinds of rulemaking also suggests that these consequences are not likely to be as frequent, great, or detrimental in the mass of subsection (a) (2) situations as advocates of this exemption claim.

However, agencies do encounter specific situations involving subsection (a) (2) rulemaking in which a requirement that they provide advance notice and an opportunity to participate would be unreasonable. For instance, although the Department of Labor does not argue that there are any disadvantages in the elimination of section 553(a) (2)

119 Bonfield, supra note 31, at 549 n.48. See also 1969 Survey, supra note 27 (response of the Office of Economic Opportunity); S. 1663 Hearings, supra note 30 , at 325 (Department of Health, Education and Welfare). 
as it applies to rulemaking of general application, it takes a different view with respect to certain rulemaking situations of particular application.

[T] he Davis-Bacon Act and some 45 related acts for Federal and Federally-assisted construction contracts . . . . provide that the specifications for all such contracts shall require the contractor to pay to his laborers and mechanics at least the prevailing wage as determined by the Secretary of Labor. The determinations are made by the Secretary at the request of the contracting agency before the bids are let.

.. . [The vast sums spent on Federal and Federallyassisted construction] are influenced not only by the level of the wages, but also by procedures which delay commencement of the contract. The aphorism that time means money is particularly pertinent here.

[A]t present the Department of Labor issues almost 26,000 prevailing wage determinations annually, averaging about 25 separate classifications of laborers and mechanics. Each classification may include up to six separate findings as to cash wages and fringe benefits payments. The Department receives about 45,000 pieces of correspondence annually in connection with the issuance of these wage determinations [which constitute rulemaking within the definition of $\S 551(4)]$.

Application of the formal rule-making requirements of section 4 would require some 500 to 600 notices of proposed rulemaking to be published each week in the Federal Register. Interested persons would have an opportunity ... . [ to participate in each case]. The processing of the submitted data, views, and arguments could result in obvious delays and additional personnel and other costs. ${ }^{120}$

120 S. 518 Hearings, silpra note 30, at 239-40. See also 1969 Survey, supra note 27 (response of the Department of Labor). The following additional reasons are offered for exempting wage determinations from $\$ 553$ rulemaking procedures:

1. Prospective bidders and interested labor organizations receive actual notice either by means of direct distribution by this Department, distribution by a parent organization, or examination of the advertisement for bids. The constructive notice which would be given by means of the Federal Register is not necessary.

2. Since the wage determination process is in essence a continuing one, interested persons have an open-ended opportunity to submit written data, views, or arguments about prevailing wage practices in a locality. An opportunity to submit such information in the case of any one determination therefore becomes almost meaningless.

3. The issued wage determination is, in effect, tentative until there is no longer a reasonable opportunity to notify bidders of substantive changes in its terms. Under these circumstances, a separate notice of rulemaking is meaningless.

4. There is no need for any delay in effective date of the wage determination. The purpose of a delay in effective date is to permit persons affected thereby to adjust to its terms. The bid submitted by a contractor represents such an adjustment.

S. 518 Hearings, supra note 30 , at 241 . 
On this basis the Department of Labor has concluded that "there are considerable disadvantages and no corresponding advantages in the elimination of the exemptions in section 553(a) (1)-(2) as they apply to wage determinations under the Davis-Bacon Act and its related acts and the Service Contract Act." 121 In this situation, it is clear that the unusually large costs which would be imposed on the Government by required adherence to normal rulemaking procedures far outweigh the benefits of public participation. These costs include not only the direct monetary cost of administering such procedures in this unusual situation but also the likelihood of substantial, deleterious consequences to the Government's construction program. Arguments based on the sheer magnitude of rulemaking necessary in a particular situation have also been made by a number of other agencies, ${ }^{122}$ but few of them are as convincing or as extraordinary as that noted above.

Similarly, there is no doubt that repeal of the (a) (2) exemptions must not interfere with the ability of agencies to react quickly in emergency situations, or in other situations where the proper performance of their functions requires rapid action. For example, there are many situations in which the Department of Agriculture cannot give advance notice of, or allow prior public participation in, its rulemaking relating to the wheat acreage allotment or crop insurance programs. The Department must frequently make changes in the regulations relating to those programs on an emergency basis, "because of a flood, other unusual weather, plant disease or something similar. In such cases [it needs] to change the regulation and make it effective at once without giving notice or delaying the effective date." ${ }^{123}$ Similarly, agencies like the Department of Treasury and the Federal Reserve Board cannot perform their intended functions properly unless they can respond instantaneously, when necessary, to a changed economic situation by promulgating rules "related to the implementation of effective

1211969 Survey, supra note 27.

122 The 1969 survey response of the Department of Agriculture's Forest Service indicates that compliance with $\$ \S 553(\mathrm{~b})-(\mathrm{e})$ would require it to publish in the Federal Register "70 percent of the Forest Service Manual and Handbook, presently consisting of approximately 30,000 pages with changes averaging 5,800 annually." An attachment to the 1969 Survey response of the Atomic Energy Commission indicates that "at present, A.E.C. Procurement Regulations consist of approximately 860 pages and require modification about 40 times a year. Other A.E.C. manuals and handbooks relating to contracts and property consist of approximately 1,000 pages and are supplemented and revised about 50 times a year." See also S. 518 Hearings, supra note 30, at 70 (Department of Defense). It should be noted, however, that much of the above would be excluded from the usual rulemaking requirements of $\$ 553$ because they are "interpretative rules" or "general statements of policy" as opposed to "substantive rules" or "legislative rules." See 5 U.S.C. \$\$553(b) (A), (d) (2) (Supp. IV, 1969).

1231969 Survey, supra note 27 (response of Production Stabilization Division, Department of Agriculture). 
monetary or fiscal policy." 124 Rules imposing immediately needed safety requirements furnish another example.

There are also specific occasions involving subsection (a) (2) rulemaking in which advance public procedures of the type listed in section 553 may cause the very evil that the proposed rules are designed to avoid. This is so, for example, in the situations just referred to relating to the implementation of an effective monetary or fiscal policy. Advance notice in such cases may unsettle the money and credit markets, present opportunities for deleterious speculative activities, and "could have generally disruptive effects on financial markets and financial institutions." 125 Another case involving an exempted subject in which adherence to usual rulemaking procedures would have caused the very evil the contemplated rule sought to avoid occurred in 1960 when the Secretary of the Interior declared a moratorium on the acceptance of applications with respect to the public lands. The reason for the moratorium was that a very large backlog of such applications had accumulated while many new ones were continuously being filed. The Department pointed out that requiring "publication in the Federal Register of a proposed moratorium would have invited a deluge of applications," making the situation much worse than it already was. ${ }^{126}$

In addition to the above, there is another class of situations involving subsection (a) (2) rulemaking in which adherence to the usual procedures involving advance notice and an opportunity to participate may be deemed unreasonable. A situation occasionally arises in which the rulemaking in question is so insignificant or minor in nature and impact that utilization of these procedures may be a complete and predictable waste. A rule requiring persons receiving federal loans or grants to sign the loan or grant instrument in ink or ball point rather than in pencil or crayon surely does not require public participation-nor, of course, do purely technical amendments to an existing rule. Similarly, if all of the information relating to the form and desirability of a given rule is necessarily within the exclusive possession of the national government because, for example, that information is a military secret or otherwise privileged from disclosure, advance notice and an opportunity to participate would be useless and a predictable waste.

The above discussion demonstrates that in certain types of cases involving rulemaking relating to "public property, loans, grants, benefits, or contracts," adherence to usual rulemaking procedures would be unreasonable. There are specific situations where the policies favoring public participation in rulemaking are outweighed by the conflicting

124 S. 518 Hearings, supra note 30 , at 51, 64-65, 395, 398, 400.

125 Id. 395, 398, 400.

126 Id. 43. 
need to operate the Government efficiently, expeditiously, effectively, and inexpensively. These situations, however, are a minority and break down into a number of well-defined classes which can be dealt with individually. They do not, therefore, constitute adequate justifications for the exemption of all rulemaking activity relating to the excepted subjects; rather, they only suggest that suitable, narrowlydrawn exceptions be provided for these atypical cases and situations. ${ }^{127}$

Finally, an interesting special argument has been made to justify the "contracts" exception. It has been argued that the "contracts" exemption should be retained in the current form because:

[I]t is more appropriate to make procedural improvements in this highly specialized field by amendments to title 41 [which deals in detail with public contracts]. The great advantage of the Administrative Procedure Act is that it can cut across a lot of statutes and give general rules for a lot of agencies where you could never catch up if you were dealing with every agency directly. But where you have one title that already sets forth very specialized procedures, if those are not proving adequate, then it seems to us that the way to correct them is to amend that title. ${ }^{123}$

This argument flies in the face of the intended function of the APA which is to achieve as much uniformity in federal administrative procedure as is reasonably possible through the use of a single comprehensive code on that subject. ${ }^{120}$ If it is reasonably possible to obtain such uniformity with respect to the procedural requirements relating to most rulemaking, including that relating to contracts, an effort should be made to do so by amending the APA.

Moreover, the above special argument supporting the "contracts" exemption may be used merely to defer action which would modify the present procedures utilized in rulemaking relating to public contracts. In fact, it is probably not of great consequence whether rulemaking relating to contracts is subjected to the requirements of section 553(b)-(e) directly, or indirectly by adding those same provisions to title 41. But the implicit suggestion in the above special argument for a section 553 contracts exemption is that contracts rulemaking should not be subjected to the exact same kind of requirements as section

127 This was recognized, for example, in the 1969 Survey response of the Department of Agriculture's Production Stabilization Division. The response stated that the Division would be disadvantaged if $\$ 553(\mathrm{a})(2)$ was eliminated because that action might make it difficult to deal with emergency situations. But the response went on to note: "It is true, of course, that notice and effective dates can be waived for cause, but an exemption, we feel, would be preferable to waivers."

128 S. 518 Hearings, supra note 30 , at 334 .

120 See sources cited note 40 supra. 
553(b)-(e) imposes. That is really why the subsection (a) (2) exemption for contracts should be retained, and any modifications of rulemaking procedure in such cases be worked, if at all, under title 41.

However, the evidence uncovered in this study does not support the need for a blanket and unqualified exemption from section 553 for all rulemaking relating to public contracts, or, for that matter, for all rulemaking relating to any of the other subjects listed in section 553 (a) (2). As subsequent discussion will demonstrate, a more narrowly tailored exemption can be devised to deal with the exceptional cases of section 553(a)(2) rulemaking that need special treatment. Consequently, no persuasive reason appears to justify a continuation of the present unqualified and across-the-board exemption for rulemaking relating to "public property, loans, grants, benefits, or contracts."

\section{Previous Proposals to Modify Section 553(a) (2)}

In almost every session of Congress during this decade one or more bills have been introduced to reform federal administrative procedure. The most important bills attempting this were S. 2335, S. 1663, and S. 1663 (subcommittee revision) of the Eighty-eighth Congress, and S. 518, S. 2770, and S. 2771 of the Ninetieth Congress. All of these bills have one thing in common concerning the present exceptive language of section $553(\mathrm{a})(2)$; they eliminated the unqualified exclusion from section 553 for rulemaking relating to "public property, loans, grants, benefits, or contracts." In its place, they substituted varying kinds of specific and general exemptions to deal with the problems that might arise from that action.

Before outlining the ways in which these various proposals have sought to resolve the problem under consideration, an introductory caveat should be stated. In their general definitional section, every one of the above bills defined "rule" as "the whole or any part of any agency statement of general applicability and future effect designed to implement, interpret or prescribe law or policy. . . ."130 The words "or particular" which appear after the word "general" in the current section 551 definition of "rule" were purposefully deleted. Rulemaking of "particular applicability" was treated by these statutes as adjudication and, as such, was governed by those provisions of the various acts. $^{131}$ This difference between the presently effective usage of the

130 S. 2771, 90th Cong., 1st Sess. §551(4) (1967); S. 2770, 90th Cong., 1st Sess. $\$ 551(5)$ (1967); S. 518, 90th Cong., 1st Sess. \$2(c) (1967); S. 2335, 88th Cong., $\$ 1001$ (c) (1964); Revised S. 1663, 88th Cong., 2d Sess. \$2(c) (1964); S. 1663 88th Cong., 1st Sess. \$2(c) (1963).

131 See, e.g., S. REP. No. 1234, 89th Cong., 2d Sess. 8-9 (1966). This report accompanied S. 1336 which was virtually the same as S. 518, 90th Cong., 1st Sess. (1967). 
term "rule," and the more restricted version just described, makes comparisons between the present statute and these proposals somewhat awkward and misleading. That fact should be kept in mind during the following discussion.

The bill sponsored by the American Bar Association, designated as S. $2335,{ }^{132}$ inserted a qualified exemption in place of the presently unqualified one for rulemaking relating to subsection (a) (2) functions. It stated that "notice of or public participation in rulemaking" would not be required with respect to rulemaking "relating to public property, loans, grants, benefits, or contracts to the extent that the agency finds and publishes, with a statement of supporting reasons, that such public participation would occasion delay or expense disproportionate to the public interest." ${ }^{133}$ Where an agency could not make such a finding, it could still utilize a generally applicable exemptive provision to adopt temporary rules relating to those subjects without giving any prior notice or chance for public participation. That provision applied "where an agency finds that (1) immediate adoption of the rule is imperatively necessary for the preservation of the public health, safety, or welfare, or (2) compliance with the requirements of this section would be contrary to the public interest." These findings, and a statement of the reasons for them, had to be published with the rule, which could not be valid for more than six months unless it was extended in compliance with the usual notice and opportunity to participate requirements of section 553. ${ }^{134}$ And finally, in no case did the ABA. bill remove the right of interested persons to petition for the issuance, amendment, or repeal of a rule, and the agencies' obligations in respect thereto.

S. $1663^{135}$ substituted for the present section 553(a)(2) exemptions a slightly different kind of qualified provision than that used by the ABA bill. In those cases where "notice and public participation would be unwarranted or contrary to the public interest," rulemaking relating to "public property, loans, grants, benefits, or contracts" was specifically excluded from every provision of section 553, including the right to petition. ${ }^{138}$ There was no requirement that the agency publish such a finding or the reasons for it with the rule so issued. Rulemaking relating to the subjects under consideration here could also be excluded from the notice and opportunity to participate provisions of section 553 under a generally applicable emergency exclusionary provision if the

132 88th Cong., 2d Sess. (1964). See S. 1663 Hearings, supra note 30, at 32. 133 S. 2335, 88th Cong., 2d Sess. § 1003(f) (2) (1964).

134 Id. $\$ 1003$ (d).

135 88th Cong., 1st Sess. 1963). See S.1663 Hearings, supra note 30, at 21. 136 S. 1663, 88th Cong., 1st Sess. $§ 4(1963)$. 
public interest demanded it. The bill stated that in any case where an agency finds, and publishes the finding and the reasons for it with the rule issued, "that adoption of the rule without notice is necessary in the public interest," it may do so. However, in such situations the emergency rule could not be effective for more than six months, and could be renewed only by commencement of a rulemaking proceeding following usual procedures. ${ }^{137}$

The Senate Subcommittee on Administrative Practice and Procedure brought out a revised version of S. $1663^{138}$ which completely abandoned the specific qualified exemption for "public property, loans, grants, benefits, or contracts" found in the original version of the bill. Revised S. 1663 contained no exception of any kind for rulemaking relating to these subjects as such. The modified bill did, however, continue in almost identical terms, and under almost the exact same limits as the original, the general emergency exemption from the notice and public participation provisions for all rulemaking that needed such treatment because it was "necessary in the public interest." The revision also added an additional general exemption to the notice provision for "minor revisions and refinements of rules." 139

The rulemaking section of S. 518 of the Ninetieth Congress ${ }^{140}$ was almost identical to the rulemaking section of S. 1336 of the Eightyninth Congress, which passed the Senate in 1966. ${ }^{141}$ In neither bill did the rulemaking section mention "public property, loans, grants, benefits, or contracts" as such. This meant that rulemaking involving those subjects was governed by the procedures usually required, unless in some particular case it came within one of the express general exclusions added to section 553 in place of the section 553 (a) (2) exclusions which had been deleted. The newly added exclusions in S. 518 exempted from every provision of the rulemaking section, including the right to petition subsection, "minor exceptions from, revisions of, or refinements of, rules which do not affect protected substantive rights," and "rulemaking that relates solely to the establishment or revision of monetary rates or policy." ${ }^{142}$ Additionally, S. 518 continued in

137 Id. $\S 4(\mathrm{~b})$.

138 88th Cong., 2d Sess. (1964). See S. 1663 Hearings, supra note 30, at 1.

139 Revised S. 1663, 88th Cong., 2d Sess. \$4(b) (1964). A permanent exemption, not relevant to this discussion, was also provided for rules relating to foreign affairs and national defense or to internal management or personnel of an agency. Id. $\$ 4$.

140 90th Cong., 1st Sess. (1967). See S. 518 Hearings, supra note 30, at 2.

141 S. 1336, 89th Cong., 2d Sess. (1966). See S. 518 Hearings, supra note 30, at 1. The only relevant difference in the rulemaking sections of the two bills is that S. 518 added an exemption for "rulemaking that relates solely to the establishment or revision of monetary rates or policy" [ $\$ 4(h)(6)]$ to the other exemptions from $\$ 4$ already contained in S. 1336.

142 S. 518, 90th Cong., 1st Sess. §4(h) (1967). 
very similar form the generally applicable emergency rules exemption found in both S. 1663 and revised S. 1663..$^{143}$

As a result of hearings held on S. 518 two modifications of that bill were proposed. The first of these was S. $2770,{ }^{144}$ which was similar to $S .518$ in every respect relevant to the discussion here, except that it added an additional exemption to help compensate for the elimination of the subsection (a) (2) exclusions under consideration. The added exemption relieved "rulemaking that relates solely to . . . wage determinations" ${ }^{145}$ from every provision of the rulemaking section, including the right to petition subsection.

The second modification of S. 518 introduced a number of sharp changes from the original. S. $2771^{146}$ contained all of the exemptions found in S. 518 discussed previously except that relating to minor exceptions or revisions. In addition, it completely and unqualifiedly excluded from every part of the rulemaking section "rulemaking that relates to public contracts." ${ }^{147}$ In so doing, it treated "contracts" differently than "public property, loans, grants [and] benefits," which were nowhere referred to in the Act as such. This bill also contained two generally applicable exemptions not present in S. 518. It completely excluded from every requirement of section 553 , including the right to petition, "rulemaking that relates solely to the establishment or revision of monetary rates, monetary policy, or other matters, with respect to which notice of proposed rulemaking would seriously impair the effectiveness of the rule." 148 It also exempted from every requirement of section 553 "situations in which the agency finds (and incorporates in the finding a brief statement of the reasons therefor in the rules issued) that notice and public procedures thereon are impracticable, unnecessary, or contrary to the public interest." 149

Prior discussion presents only the general outlines of the most important previous efforts to alter section 553(a) (2). It demonstrates that much consideration has been given to the elimination or modification of these exemptions and that there is substantial agreement that some change with respect to the subsection (a) (2) exclusions is necessary. Most of the above proposals, however, do not present as desirable a solution for the problem at hand as that to be discussed in the next section. They are not narrowly enough tailored to secure the best

143 Id. $\$ 4$ (d).

144 90th Cong., 1st Sess. (1967).

145 S. 2770,90 th Cong., 1st Sess. § 553(h) (6) (B) (1967).

146 90th Cong., 1st Sess. (1967).

147 S. 2771, 90th Cong., 1st Sess. $\$ 553(\mathrm{~h})(5)$ (1967).

$148 I d$. $\$ 553(\mathrm{~h})(6)$. The language commencing with "or other matters" is not present in S. 518 .

$149 \mathrm{Id}$. $\S 553(\mathrm{~h})(4)$. 
accommodation of the competing interests involved. Almost all of the prior bills seek to deal with problems arising from the repeal of subsection (a) (2) through the use of new exemptive language, most of which is not demonstrably superior to existing language of section 553 that could be used as efficiently for the same purpose. Consider the following illustrations.

As noted earlier, the continued exclusion of all rulemaking relating to contracts, which is a feature of S. 2771, seems unwarranted. Similarly, the express exclusions for "all rulemaking that relates solely to the establishment or revision of monetary rates or policy" as found in S. 518 and S. 2771 may also be overbroad as a rational accommodation of the interests involved. Some rulemaking within this definition might not need to be excluded from the ordinary rulemaking procedures of section 553. For instance, setting the discount rate for banks needs to be done without prior public notice. But a proposed rule limiting the rate of interest that may be paid by member banks of the Federal Reserve System on time or savings deposits to no more than "the applicable maximum rate authorized by law to be paid upon such deposits by State banks or trust companies organized under the laws of the State in which such member bank is located," 150 may not need to be exempted from usual rulemaking requirements-even though such a rule may "relate solely to the establishment or revision of monetary rates or policy." The exemption for rulemaking that "relates solely to . . . wage determinations" found in S. 2770 may also be overbroad. It not only exempts such rulemaking in an unusual situation like that faced by the Department of Labor, but in all situations, regardless of the particular circumstances of the case. Moreover, it not only exempts the wage determinations themselves, but also all rulemaking that "relates solely to" those determinations.

New exemptive language whose function can as easily and effciently be performed by existing section 553 exclusionary terminology is also plentiful in the above bills. It was inserted to cure the problems resulting from their elimination of present subsection (a) (2). For example, S. 2335 exempts rulemaking where "such public participation would occasion delay or expense disproportionate to the public interest"; S. 1663 exempts rulemaking from usual procedures when they are "unwarranted or contrary to the public interest"; revised S. 1663 exempts all "minor revisions and refinements of rules"; S. 518 enlarges that to an exemption for all "minor revisions and refinements of rules which do not affect substantive rights"; and S. 2771 exempts from usual requirements "matters with respect to which notice of proposed

15012 C.F.R. $\$ 217.3(\mathrm{c})(2)(1969)$. See also, e.g., id. $\$ 217.2$ (prohibiting the payment of interest on demand deposits and defining interest for these purposes). 
rulemaking would seriously impair effectiveness of a rule." Subsequent discussion should demonstrate that the problems sought to be solved by inserting the above new language as a substitute for the subsection (a) (2) exclusions can easily, and perhaps more satisfactorily, be cured by other exemptive terminology already contained in section 553 .

\section{A Solution: Section 553(b) (B) And Section 553(d)(3)}

According to section $553(\mathrm{~b})(\mathrm{B})$ the provisions of section 553 (b)-(c) are inapplicable "when the agency for good cause finds (and incorporates the finding and a brief statement of reasons therefor in the rules issued) that notice and public procedure thereon are impracticable, unnecessary, or contrary to the public interest." This qualified and limited exemption from two subsections of section 553 deserves careful examination because it may be a satisfactory substitute for the overbroad, unqualified exemptions presently contained in subsection (a) (2).

The exemption found in section $553(\mathrm{~b})(\mathrm{B})$ is narrowly tailored because it requires an administrative assessment of the particular facts and circumstances surrounding each case of rulemaking to which it is sought to be applied. The reports of the Senate and House committees responsible for the APA clearly stated that

[t] he exemption of situations of emergency or necessity is not an "escape clause" in the sense that any agency has discretion to disregard its terms or the facts. A true and supported or supportable finding of necessity or emergency must be made and published. ${ }^{151}$

By this, committees intended to establish a restrictive meaning of the terms "when the agency for good cause finds" which precede the enumeration of grounds upon which this particular exemption is available.

Therefore, the agencies are required under this provision to make specific findings, meeting what has been interpreted to be a strict standard, before they can avail themselves of the exemption. Some commentators have argued that the courts should not examine the accuracy of the required administrative finding when the validity of an agency's use of this exemption arises in litigation. ${ }^{152}$ However, this finding is judicially reviewable on the same basis as any other finding Walter).

151 S. Doc. No. 248, supra note 2, at 200, 258. See also id. 358 (remarks of Rep.

152 See R. Parker, Admintstrattve Law 182-83 (1952) ; Nathanson, Some Comments on the Administrative Procedure Act, 41 ILL. L. REv. 368, 384-85 (1946). 
committed to an agency's judgment. ${ }^{153}$ Thus, if the finding is "arbitrary, capricious, an abuse of discretion or otherwise not in accordance with law" or is "unsupported by substantial evidence" based on the whole record, it will be set aside and the rule promulgated rendered invalid. ${ }^{154}$ Of course, in such cases the presumption of validity will rest, as it always does, with the administrative action, the burden of overturning it resting upon the assailant.

There is one interpretation of section 553(b) (B) which should be rejected at the outset. It can be argued that an agency seeking to come within the section 553(b) (B) exemption must find that it is "impracticable, unnecessary, or contrary to the public interest" for the agency to follow the procedures of subsection (b) in each separate rulemaking case to which it seeks to apply the exemption, and that it cannot make that finding wholesale as to any narrowly tailored class or group of rulemaking situations. This interpretation relies upon certain somewhat ambiguous language in the provision: "when the agency for good cause finds (and incorporates the finding and a brief statement of reasons therefor in the rules issued)." It also relies upon the supposed intention of Congress to provide a means by which individual cases could be separately considered on their own merits, and an exemption granted only in those specific cases in which it was justified on one of the grounds stated.

While the above argument has great merit and is a sound general rule by which to construe section 553 (b) (B), it overlooks two points. First, it may be "impracticable, unnecessary, or contrary to the public interest" to follow usual section 553 procedures in every single instance of a specific type of rulemaking under a particular statute, when each such instance is viewed in isolation. In those circumstances it seems a foolish waste to require repetitive and redundant findings and full publication of those findings. As will be explained later, rulemaking setting the discount rate for the Federal Reserve System is an example of that kind of situation. ${ }^{155}$

Second, there are also situations where compliance with the procedures of section $553(\mathrm{~b})-(\mathrm{c})$ is not "impracticable" or "contrary to the public interest" as applied to any single instance of rulemaking on a given subject, but becomes so as to a whole class if those requirements must be followed for all such similar instances of rulemaking. For

153 See Texaco, Inc. v. FPC, 412 F.2d 740 (3d Cir. 1969); Durkin v. Wagner Co., 115 F. Supp. 118 (E.D.N.Y. 1953) aff'd per curiam sub nom. Mitchell v. Wagner Co., 217 F.2d 303 (2d Cir. 1954), cert. denied, 348 U. S. 964 (1955). See also National Motor Freight Traffic Ass'n, Inc. v. United States, 268 F. Supp. 90 (D.D.C. 1967). In this last case, it is not clear whether $\$ 553(\mathrm{~b})(\mathrm{B})$ or $\$ 553(\mathrm{~B})(\mathrm{A})$ was involved. 1545 U.S.C. $\$ \$ 706(2)(A),(2)(E)$ (Supp. IV, 1969). See also cases cited note 153 supra.

155 See text accompanying note 185 infra. 
example, so many different rules of a particular type may have to be issued within a short time period that affording notice and an opportunity to participate in every such case would be practically impossible, would frustrate the proper performance of the agency's functions, or would cause other substantial deleterious consequences. The wage determinations made by the Department of Labor under the DavisBacon and related acts provide an example of such a situation. Procedures of the type specified in section 553 may not be "impracticable" or "contrary to the public interest" with respect to any one such determination viewed in isolation; but those procedures undoubtedly become so when they must be applied to all such determinations.

As a result, the exemption contained in section 553(b) (B) should be read to allow an agency to make the requisite finding for a whole class of rulemaking. But this should only be permitted if the agency can either make that finding as to every single member of the class considered separately, or as to every single member of the class because it would be "impracticable" or "contrary to the public interest" to impose section 553 procedures on all members. Of course, agencies must be required to draw their classes for this purpose as narrowly as possible in order to exclude no more under this exception than is absolutely justifiable in terms of the statutory criteria. Overbreadth of any kind in the drawing of such a class of rules should not be tolerated. Consideration might also be given to shifting the burden of proof to the agency with respect to such group as opposed to individual case delineations, thus forcing the agency to justify its definition of a "class" of rulemaking sought to be excluded from usual procedures. Such a limitation, however, may not be necessary and may have some undesirable consequences.

The grounds specified in section 553(b)(B) upon which an agency may dispense with the usual rulemaking procedures are stated in the alternative, so that any one of the three grounds listed is sufficient to invoke the exemption. ${ }^{156}$ The first ground upon which the qualified exemption becomes available is when the notice and participation requirements of section 553 are found to be "impracticable." Webster defines the term as meaning, among other things, "infeasible," "impractical, unwise, imprudent." ${ }^{157}$ Earlier drafts of the APA would have made the exemption available when the public rulemaking procedures were "impracticable because of unavoidable lack of time or other emergency," 158 but the qualifying language after "impracticable" was

156 Attorney General's Manual, supra note 11, at 30.

157 Webster's New International Dictionary 1136 (3rd ed. 1966).

158 S. Doc. No. 248 , supra note 2 , at $140,148,157$. See also id. 181. The version at 181 reads, "impracticable because of unavoidable lack of time or other emergency affecting public safety or health." 
subsequently dropped. The Senate and House reports on the APA stated that "impracticable" means a situation "in which the due and required execution of the agency functions would be unavoidably prevented by its undertaking public rule-making proceedings." 159

The term "unnecessary," which is the second exemptive ground specified in section 553 (b) (B), connotes something which is "not necessary: useless, needless." ${ }^{160}$ The legislative history indicates that it must be unnecessary "so far as the public is concerned, as would be the case if a minor or merely technical amendment in which the public is not particularly interested were involved." 161 On this basis one court seems to have concluded that "unnecessary" applies to situations in which an agency rule is "minor or emergency in character," 162 or "'a routine determination,' 'insignificant in nature and impact,' and unimportant 'to the industry and to the public.' "163

Rulemaking is also exempted by section 553(b) (B) from advance notice and public participation when adherence to those procedures would be "contrary to the public interest." According to the APA's legislative history, this phrase "supplements the terms 'impracticable' or 'unnecessary'; it requires that public rulemaking procedures shall not prevent an agency from operating and that, on the other hand, lack of public interest in rulemaking warrants an agency to dispense with public procedure." ${ }^{164}$ The Attorney General's Manual takes the position that " 'public interest' connotes a situation in which the interest of the public would be defeated by any requirement of advance notice." 165

At some point during their legislative history all three terms"impracticable," "unnecessary," and "contrary to the public interest"were referred to as operating "only where facts and interests are such that notice and proceedings are impossible or manifestly unnecessary" 160 and as exempting "situations of emergency or necessity." 167 However, the weight of their legislative history, as well as their language, clearly establishes that these terms were not meant to be so narrowly limited. At the same time it must be remembered that these are qualified grounds for exemption and are not to be construed more broadly than the demands of sound government administration and wise public policy

159 Id. 200, 258. Accord, Attorney General's Manual, supra note 11, at 30 . 160 Webster's NeW International Dictionary 2504 (3rd ed. 1966).

101 S. Doc. No. 248, supra note 2, at 200, 258. See also Attorney General's MaNual, supra note 11, at 31 .

162 Texaco, Inc. v. FPC, 412 F.2d 740, 743 (3d Cir. 1969).

163 Id. at 743 (citing National Motor Freight Traffic Ass'n v. United States,

268 F. Supp. 90, 95-96 (D.D.C. 1967).

164 S. Doc. No. 248, supra note 2 , at $200,258$.

165 Atrorney Generat's ManUal, supra note 11, at 31 .

166 S. Doc. No. 248 , sipra note 2 , at 358.

167 Id. $200,258$. 
require. It is worth repeating that the section 553 (b) (B) exemption is "not an 'escape' clause in the sense that an agency has discretion to disregard its terms or its facts." 168 An agency can use this exemption only if it has "good cause" within the provisions of the Act.

A more detailed description of how the section 553(b) (B) exemption might operate in practice will demonstrate that it could satisfactorily handle the problems resulting from a repeal of section 553 (a) (2) -and do so on the basis of a rational accommodation between the need for public participation in rulemaking on the one hand, and the need for efficient, effective, expeditious, and inexpensive government administration on the other. Although the terms "impracticable," "unnecessary," and "contrary to the public interest" overlap to some extent, an effort will be made, insofar as possible, to examine their applications separately. But it should be remembered that in light of the very close relationship between these terms, the following analysis of their applications should also be considered as partially overlapping.

Consider the exemption for situations where public procedures are found to be "unnecessary." This could undoubtedly perform the function intended by the exception for "minor revisions and refinements of rules" found in several of the bills discussed earlier, and probably more satisfactorily so because the existing term may be more narrowly tailored. For example, the "unnecessary" exemption seems to cover situations where a rule involved is in fact of such a minor nature, like the rule requiring government loan instruments to be signed in ink, that public procedures would be a predictable and indisputable waste. Also under this "unnecessary" exemption, public procedures may be dispensed with for rules announcing the exact penalty rates applicable to the marketing of certain commodities in excess of the farm-marketing quota. The Department of Agriculture's action in those cases only involves a mathematical computation, the statute specifying that the rates are to be a certain percentage of parity or support price of the commodity as of a particular date. ${ }^{169}$ Similarly, usual rulemaking procedures are also "unnecessary" for mere technical changes in regulations. If, for example, the statute citations contained in a regulation must be altered to conform to changes in the numbering of the United States Code, or regulations are rewritten or reorganized purely for style, with no substantive changes, public procedures are obviously "unnecessary."

On the other hand, under this exemption agencies should not be permitted to decide lightly that public procedures are "unnecessary."

168 Id. See text accompanying note 152.

1691957 House Study, sipra note 51, at 26-27. 
In Texaco, Inc. v. Federal Power Commission ${ }^{170}$ the Third Circuit Court of Appeals considered an FPC regulation which had been promulgated without resort to the public procedures of section $553(\mathrm{~b})-(\mathrm{c})$. The regulation required natural gas companies to pay a compound interest rate, for the first time, on all amounts refunded to their customers because of overcharges resulting from new rates subsequently found to be unjustified. After considering all of the Commission's arguments, the court held that the rule was invalid because of the failure to follow section 553 (b)-(c) procedures in its promulgation.

The court in Texaco explained that "the rule does not fall within the 'unnecessary' exception relied on by the Commission since it cannot be classified as either minor or emergency in character." 171 The court refused to accept the argument that the section 553 procedures were "unnecessary" because they found that "the compound rate would affect numerous jurisdictional gas companies and potentially involves large sums of money." 172 The court also expressly rejected the Commission's contention that the procedures were "unnecessary" because the new rule imposed no obligation on affected parties that could not have been imposed on them by ad hoc adjudicatory orders in each case. "The crucial fact is that the Commission elected to proceed in the case by making a general rule and, when engaged in rulemaking, it must comply with the procedural requirements imposed on rulemaking by the Administrative Procedure Act, which it failed to do. . . ."173

By holding as it did, the court in the Texaco case seems to have taken the position that the ability of an agency to achieve the same result as a rule by another means, such as through ad hoc adjudication, does not make the requirements of section 553(b)-(c) "unnecessary" when the agency in fact elects to achieve that result through rulemaking. This is not the place to fully explore the wisdom of that result. ${ }^{174}$ However, a number of general points are worth making here. The result in Texaco can be justified in light of the fact that the APA favors public participation in rulemaking in all cases except those where very good reasons preclude it; the fact that the rule was not minor in its effects, and had a large financial impact on many companies; ${ }^{175}$ and the fact

170412 F.2d 740 (3d Cir. 1969).

171 Id. at 743 .

$172 I d$.

173 Id. at 745.

${ }^{174}$ Cf. NLRB v. Wyman-Gordon Co., 394 U.S. 759 (1969) (holding an agency order issued to a party in the course of an adjudicatory proceeding valid and enforceable, even though the same requirement announced in the course of an adjudication as a prospective rule only would be void because it failed to follow the rulemaking requirements of $\$ 553)$. See generally Comment, Wyman-Gordon and the Excelsior Rule, 117 U. PA. L. REv. 621 (1969).

175412 F.2d at 743 n.7. 
that the agency did make a conscious choice to proceed by rulemaking which would result in an order of general applicability rather than by an ad hoc order in each case. ${ }^{176}$ On the other hand, one of the undesirable effects of this decision may be to discourage the use of general rules in favor of ad hoc adjudication, a result which is usually contrary to the sound administration of regulatory policies. ${ }^{177}$

The "unnecessary" exemption should not allow agencies to avoid section $\mathbf{5 5 3}$ procedures merely on the ground that a rule is "minor" or "unimportant" because it only has a small impact on a very limited segment of the public. It is wise to have well-informed decision-making and citizen-participation in government rulemaking which has a relatively small impact on limited segments of the public, as well as in those actions which have a great impact on large portions of the public. Consider the following case, for example.

One congressional office got a host of complaints from people, not only in that area, but throughout the country, on an unimportant rule which an agency had made without any public notice or hearing, related to public property. It related to how many pounds of petrified wood you could take off the premises of a national reservation of some type. And this agency had thought-well, it is a terrible thing to lose all these hunks of stone, so they-within their own internal organization, they came up with one pound, or something like that.

This provoked all this correspondence to Congress.

So the congressional people involved went down to the agency . . . [which] said-"Oh, well, we realize we made a mistake, we will raise it to five pounds." So the congressmen went back and said we solved the problem. The agency said yes, very unimportant.

Well, that provoked ten times more mail than came in the first time, because it turned out that five pounds just didn't qualify under the standards by which petrified wood is traded in the market of . . . collectors. . . . It has to be a bigger poundage.

Well, the moral of that particular story was that this supposedly minor rule . . . turned out to be important to a lot of people in this country, and the fact that the agency did not give public notice, and give the public a chance to express

176 Id. at 744 n.9.

177 See United States v. Storer Broadcasting Co., 351 U.S. 192, 203 (1956); NLRB v. Majestic Weaving Co., 355 F.2d 854, 860 (2d Cir. 1966). See also Auerbach, Should Administrative Agencies Perform Adjudicatory Functions?, 1959 WIs. L. REv. 95; Shapiro, The Choice of Rulenaking or Adjudication in the Development of Administrative Policy, 78 HARv. L. Rev. 921 (1965). 
its opinion, caused a heck of a lot of trouble for an awful lot of people. ${ }^{178}$

The "impracticable" exemption could adequately deal with a number of different situations in which a requirement of advance notice of rulemaking and public participation therein would be unreasonable. In cases of emergency where a rule is needed immediately in order to avoid injury or frustration of a program's objectives, the usual section 553 (b)-(c) procedures can be disregarded because they are "impracticable." According to the Attorney General's Mamual, for example, "the Civil Aeronautics Board may learn, from an accident investigation, that certain rules concerning air safety should be issued or amended without delay; with the safety of the traveling public at stake, the Board could find that notice and public rule-making procedures would be 'impracticable,' and issue its rules immediately." 178 Similarly, where haste is needed, safety rules applicable to trucks and railroads, and rules regarding the marking, packing, and handling of dangerous items like explosives on such carriers, must also be permitted to avoid the usual procedures set out in section 553 (b)-(c) on the grounds that such procedures are "impracticable." 180

The Department of Agriculture has properly stated that the same rationale is equally applicable when the Department must impose or modify animal or plant quarantines promptly to prevent the spread of diseases or insect pests; or when the Department makes orders under the Packers and Stockyards Act of 1921 to continue temporary rate schedules previously authorized after notice and an opportunity to be heard, if prompt action is necessary to avoid a reversion to rates and charges that are unrealistic in light of existing economic conditions; or when the Department finds that last minute changes are necessary in acreage allotments and marketing quota regulations under the Agricultural Adjustment Act of 1938, because farmers must know of such changes prior to planting. ${ }^{181}$ To force adherence to the procedures of section 553 in any of these situations would be "impracticable" because time is of the essence.

Consider also the situation presented in the case of Durkin $v$. Edward S. Wagner Co. ${ }^{182}$ In a prior decision involving the same parties, the court had held that particular workers were not covered by certain regulations under the Fair Labor Standards Act. This

178 ABA Symposium on S.1336, Washington, D.C., Dec. 1, 1966, Transcript 110-11. 179 Attorney General's Manual, supra note 11, at 30-31.

1801957 House STUDX, supra note 51, at 1760 (Interstate Commerce Commission). 181 Id. 26-27. See also Dighton v. Coffman, 178 F. Supp. 114 (E.D. I11. 1959), aff'd, 279 F.2d 497 (7th Cir. 1960).

182115 F. Supp. 118 (E.D.N.Y. 1953), aff'd per curiam sub nom. Mitchell v. Wagner Co., 217 F.2d 303 (2d Cir. 1954), cert. denied, 348 U.S. 964 (1955). 
holding was contraty to the interpretation and practice of the Administrator of the Wage and Hour Division, an interpretation known and relied upon by the industry involved. As an immediate response to this decision, and without resort to usual rulemaking procedures, the Administrator promulgated a rule which included those workers within the relevant regulations.

When he issued the new rule, the Administrator stated that it would be "impracticable, unnecessary, or contrary to the public interest" to follow usual rulemaking procedures in the making of this "clarifying" regulation. "[I] mmediately effective clarification of the regulations is essential in order to accomplish the intent of the present regulations to safeguard the wage standards in the industry, to eliminate the unfair competitive situation, and to provide for adequate enforcement of the home work restrictions." 183 On the basis of this evidence, and the absence of any evidence to controvert it, the court held that the rule involved was properly treated as within the section $553(\mathrm{~b})(\mathrm{B})$ exception. ${ }^{184}$

The court's result seems justifiable because any delay in promulgation of the rule would have encouraged employers to abandon their previous adherence to the Administrator's interpretation of the earlier rule until a new rule to the same effect was formally adopted. This would have hurt countless employees who had come to rely on the fruits of the prior interpretation. It also would have injured those employers who chose, despite their competitors' contrary action, to keep their wages at the levels demanded by the earlier interpretation of the Administrator during the period in which the new rule was being adopted with public procedures.

Either the "impracticable" or "contrary to the public interest" exemption, or both, must be deemed to cover rulemaking relating to the debt management functions of the Treasury when notice and public participation would result in frustration of the Department's operations in that regard, or in other undesirable consequences. Either of those exemptions could also cover rulemaking such as that determining "discount rates established by Federal Reserve Banks, and changes in gen-

$183 \mathrm{Id}$. at 122.

184 Id. at 122-23. On appeal the court said:

Judge Galston has found that the defendant's operations fall within the amended regulations and that the regulations were properly promulgated under the Administrative Procedure Act, 5 U.S.C. \$1003(a). D.C.E.D.I.Y., 115 F. Supp. 118. We see no reason to overturn his well-reasoned conclusions. While there was no advance notice of the amendment, yet that was not necessary, both because of its nature as an "interpretive" rule and because of the Administrator's finding of "good cause" for immediate action, based upon the fact that other employers in general were complying with this interpretation of the Act and defendant had long known of the view held by the Administrator.

217 F.2d at 304. 
eral requirements regarding reserves of member banks, maximum interest rates on time and savings deposits, or credit for purchasing or carrying securities." The delay involved in according prior notice and public participation in those cases would ordinarily "prevent the action from becoming effective as promptly as necessary" to meet current economic exigencies, thereby making such procedures "impracticable" under those circumstances. The delay involved in adherence to usual procedures might also "permit speculators or others to reap unfair profits or to interfere with the Board's action taken ...."185 The next exemption to be discussed focuses on these latter problems.

An agency can ignore usual rulemaking procedures under section 553 (b) (B) whenever advance notice would tend to defeat a rule's purpose because in such situations those procedures would certainly be "contrary to the public interest." 186 The function sought to be performed by the exemption found in one of the bills discussed earlier for "matters with respect to which notice of proposed rulemaking would seriously impair effectiveness of a rule," is adequately performed by the existing "contrary to the public interest" terminology. For example, the Securities and Exchange Commission "has often deemed it inadvisable to submit a proposed regulatory rule to the industry because of the danger that certain companies might take advantage of the interim period to effect transactions which the rule is designed to prevent or control and thus escape the intended regulation of conduct altogether." 187

The Department of Commerce has reported that "[i]n the exercise of [its] priority and allocation functions [under the Defense Production Act of 1950], speed in the issuance of orders and regulations is often essential as prior notice of proposed governmental action would tend to defeat the purpose intended to be accomplished thereby. For example, notice of intention to place certain materials under production control or to limit acquisition thereof might create panic buying in an effort to get the jump on the regulation and on competitors." ${ }^{188}$ In such cases the Bureau of Defense Services Administration properly invoked the section 553(b) (B) exemption on the grounds that adherence to usual procedures in that situation would be "contrary to the public interest." 189 Similarly, the Department of Interior rule placing a

18512 C.F.R. $\$ 262.2(\mathrm{e})(1969)$. See also S. 518 Hearings, supra note 30, at 366-67. 186 See 1941 Hearings, supra note 17, at 812. See also Attorney General's Manual, supra note 11 , at 31 .

187 B. Schwartz, AN Introduction to American Administrative Law 62 (1958).

1881957 HouSE STUDY, supra note 51, at 115.

$189 \mathrm{Id}$. 
moratorium on applications respecting the public lands, would also fit within the exception.

There is also no reason why the "contrary to the public interest" language of section 553 (b) (B) cannot be used satisfactorily to work an overt accommodation between the need for public rulemaking procedures on the one hand, and the need for inexpensive, expeditious, effective, and efficient government administration on the other. The function performed by language like "occasion delay or expense disproportionate to the public interest," which appeared in one of the bills discussed previously, can easily be performed by balancing the relevant considerations under a standard such as "contrary to the public interest."

The "contrary to the public interest" terminology should allow the Department of Labor an exemption for the wage determinations it makes under the Davis-Bacon and related acts. Because of the especially large number of such "rules" that the Department must continually make during a limited period, required adherence to usual rulemaking procedures in that situation would cause an unusually large delay and/or increase in costs of all kinds. These extraordinary deleterious consequences resulting from the peculiar facts of the administration of this program outweigh any positive good that might result from requiring adherence to normal rulemaking procedures. The existence of seemingly successful alternative procedures to provide interested persons with adequate notice of, and a chance to contribute views in relation to, those wage determinations eliminates any possibility that the Department should have to adhere to section 553 procedures in this situation. ${ }^{190}$

190 S. 518 Hearings, supra note 30 , at 92,95 (statement of the AFL-CIO). In addition, the Solicitor of Labor stated:

The actual wage determination procedure is initiated by the procurement agency, which submits its request for a finding of wage rates prevailing in the locality of the proposed project for the various classes of laborers and mechanics whose employment is required.

The request is usually made about thirty days before any advertisement of specifications or the beginning of negotiations, as the case may be.

Where the information on hand as a result of the continuing program referred to is sufficient to make findings, a decision is made.

If the information is not sufficient, a field survey is made. In the course of the survey, local labor organizations, contractors, contractors' groups and public agencies are contacted. Hearings may also be held in order to amplify further the record upon which findings are to be based.

When the findings are made, and the wage determination is issued to the requesting agency, copies of the wage determination are promptly sent to labor organizations and contractor associations with the understanding that they will be distributed to any local affiliates which may have an interest in the wage determination. This is done in order to afford interested persons an opportunity to present timely requests for changes in the wage determination upon the basis of any evidence that they may have.

Interested persons may appeal for review of wage determinations by the Department's Wage Appeals Board, which is empowered to pass upon all questions of law and fact. 
Similarly, the "contrary to the public interest" standard found in section 553(b) (B) should permit exemptions for other extraordinary situations. Where the delay and costs involved are in fact so very large, due to the special facts of the case, that they outweigh the strong public interests favoring adherence to usual rulemaking procedures, an exception could be allowed. More than just "any increase in cost or delay" will be necessary to justify such an exception under the "contrary to the public interest" standard. The facts will have to demonstrate that an atypically large delay or increase in cost will result from adherence to normal rulemaking procedures, and that the extraordinary delay or cost is not outweighed by the benefits of adherence to those usual procedures. Situations of this sort will be relatively few. Those increased costs and delays which are ordinarily to be expected are properly treated by the Act as an acceptable quid pro quo for the important benefits achieved by requiring advance notice and public participation under section 553 .

Section 553(d) (3) should perform the same function for section 553 (d) as section 553 (b) (B) performs for section 553 (b) - (c). According to section $553(\mathrm{~d})(3)$, an agency can dispense with the section 553 (d) required publication or service of a substantive rule at least thirty days before its effective date, whenever the agency decides to do so "for good cause found and published with the rule." This "good cause" exemption should give agencies at least as much discretion to avoid the application of section 553(d) in appropriate cases as the "impracticable, unnecessary, or contrary to the public interest" exemption gives them to avoid the application of section 553(b)-(c). Indeed, the former may give agencies even more discretion than the latter because the guiding terms "impracticable, unnecessary, or contrary to the public interest" are conspicuously absent from section 553(d)(3).

Nevertheless, in order to make the requirements of section 553 (d) meaningful, the exemption from its terms should be construed to be as broad, but no broader, than section $553(\mathrm{~b})(\mathrm{B})$. If that is so, the "good cause" required by section 553 (d) (3) must, like the "good cause" required by section 553 (b) (B), be predicated on a finding that adherence to usual procedures is "impracticable, unnecessary, or con-

Substantive changes may be made in wage determinations without exception up to the ten-day period before the opening of bids for the construction work. Thereafter, and until the award of the contract, a substantive change may be made only where the procurement agency finds that there is a reasonId. 240.

able time in which to notify the bidders of the change.

In those cases in which the Department serves personal notice of the wage determinations on the parties "subject thereto," or those parties have notice thereof as provided by law, the Department can dispense with the usual advance notice and public participation requirements because of $\$ 553(\mathrm{~b})$, and need not even rely on a modified $\$ 553(\mathrm{~b})(\mathrm{B})$. See also text accompanying note 203 infra. 
trary to the public interest." The legislative history of the "good cause" exception in section 553(d) (3) supports the conclusion that the two exemptions should be treated as congruent. The House Report on the APA states that:

[This] exception-upon good cause found and published-is not an "escape clause" which may be exercised at will but requires legitimate grounds supported in law and fact by the required finding. Many rules . . . may be made operative in less than 30 days because of inescapable or unavoidable limitations of time, because of the demonstrable urgency of the conditions they are designed to correct, and because the parties subject to them may during the usually protracted hearing and decision procedures anticipate the regulation. ${ }^{191}$

Previous discussion should demonstrate that if the section 553(a) (2) exemptions under consideration were eliminated, the exclusions found in section 553 (b) (B) and section 553 (d) (3) could adequately handle any peculiar problems created thereby. Where a rational balancing of the relevant interests would indicate the desirability of an exception from the requirements imposed by section 553(b)-(d) for particular rulemaking, the above "good cause" exemptions could suffice to achieve the result.

No special exemption is needed from the right to petition provision of section 553(e) if the subsection (a) (2) exclusions are repealed. Interested parties should always have the right to petition for the issuance, amendment, or repeal of a rule. As noted earlier, the only obligation which that right imposes on an agency is the duty to follow its own rules with respect to such petitions, and the duty to respond under section 555 (e) by giving " [p] rompt notice . . . of the denial in whole or in part of a . . . petition . . . accompanied by a brief statement of the grounds for denial." If the need arises, an agency may respond to a group of similar petitions as an entity. Consequently, no situation involving one or more petitions for a rule relating to the subsection (a) (2) subjects would seem to require even a qualified exemption from section 553(e). Currently no exemption from the right to petition requirement is deemed necessary for any rulemaking already subject to the terms of section 553. In light of the importance of that right, and the minor burden it imposes on agencies, this position seems fully justifiable.

If the right to petition continues unhampered by any exceptions even after the subsection (a) (2) exemptions are removed, an important salutary consequence will follow. In every case where usual public

191 S. Doc. No. 248, supra note 2, at 260. See also id. 201 ; Buckeye Cablevision, Inc. v. F.C.C., 387 F.2d 220, 228 n.34 (D.C. Cir. 1967). 
procedures are dispensed with prior to the promulgation of a rule because the qualified exemptions of section 553(b)(B) are applicable, interested parties will have an effective chance to express their views on that rule subsequent to its enactment. They can file a petition for the amendment, repeal, or modification of the rule in question, including a statement of their reasons therefor. The agency will then be obliged to respond, as section $555(\mathrm{e})$ requires, with " $[\mathrm{p}]$ rompt notice . . . of the denial in whole or in part of ... [the] petition . . accompanied by a brief statement of the grounds for denial," unless it affirms a prior denial or the denial is self-explanatory. It should be recalled that the previously discussed bills to reform section 553 required initiation of public procedures within a stipulated period after an emergency rule was promulgated in order to continue its effectiveness. Such an approach has merit in assuring public participation subsequent to a rule's issuance in those cases in which it was impossible beforehand. The right to petition should provide some of the same protection.

The section 553(b) (B) and section 553(d) (3) exemptions impose a special obligation of disclosure on agencies utilizing those provisions. An agency must incorporate in the rules issued without following usual procedures the necessary statement of "good cause" predicated upon a finding that adherence to section 553 (b)-(d) is "impracticable, unnecessary, or contrary to the public interest"; it must also include a brief statement of the reasons for that finding. In cases where the exemption is utilized based on a finding with respect to a whole class of cases, only one such full publication relating to the whole class should be required. Rules in that class subsequently issued without resort to usual procedures would only need to refer to the prior full publication of findings and reasons, and give its citation. To be of value, the reasons listed in the rules as justification for the failure to follow usual procedures must, of course, be fairly specific. Declarations in the language of the Act will not satisfy this requirement and should be deemed inadequate under the statute. At the same time the required statement of reasons need not be so detailed as to be unduly onerous.

The above disclosure obligation will have two salutary effects. First, such a requirement will force the agency to consider very carefully its reasons for each such action. Second, by requiring an official statement of the agency's reasons for using the exemption, judicial review of that action will be facilitated. If such action is challenged in a judicial proceeding, the court can test its validity against the reasons provided in the prior publication. Having stated the reasons for their conduct in this regard both formally and publicly, agencies will presumably not be allowed to assert others as justifications if the ones 
originally given prove to be inadequate. This should keep agencies both thoughtful and honest in the use of this exemption.

The survey prepared specially for this study asked all federal agencies the following question:

Why are the several specific exemptions currently contained in $\S 553(\mathrm{~b})$-(e) insufficient to deal with any disadvantages that might be encountered by your department or agency if all of $\S 553(\mathrm{a})(1)-(2)$ was repealed? Among these specific exemptions just referred to is that contained in $\S 553$ (b) (B) providing that public notice of rulemaking and participation by interested persons in rulemaking is not required "when the agency for good cause finds (and incorporates the finding and a brief statement of reasons therefor in the rules issued) that notice and public procedure thereon are impracticable, unnecessary, or contrary to the public interest."

Agencies making rules presently exempted by subsection (a) (2) from section 553 responded in various ways to this question. These responses, and the following discussion of section $553(\mathrm{~b})(\mathrm{B})$, may also be considered applicable to the section 553 (d) (3) exemption since, as noted earlier, the requirements of that exemption are probably congruent with those of section 553 (b) (B).

Some respondents to the above question insisted that the section 553 (b) (B) exemption was an insufficient substitute for subsection (a) (2) because the latter is necessary as it is, and the former is not as broad as the latter. ${ }^{192}$ Responses of this sort are of little help in evaluating the impact that the proposed changes may have, and they in no way detract from the solution previously suggested. They amount to no more than an insistence that section 553 (a) (2) is necessary, and that nothing less is acceptable, without any explanation why other existing exemptions, including section 553 (b) (B), are inadequate substitutes for the subject matter exemptions of subsection (a) (2). A frequent objection to section 553 (b) (B) as a substitute for section 553 (a) (2) is that making the findings required by the former would constitute too great an administrative burden on the agencies. ${ }^{193}$

1921969 Survey, supra note 27 (responses of Atomic Energy Commission; Post Office; Forest Service and Soil Conservation Service, Department of Agriculture). For example, the Post Office stated:

It is considered that the specific exemptions contained in Sec. 553(b)-(e) are not well adapted to serve as substitutes for the subject area exemptions. It is believed that the exemption stated in Sec. 553(a) [2] reflects a proper and generalized finding that the provisions of Sec. 553(b)-(e) are not appropriate for rulemaking in these subject matter areas and that the reasons underlying this will continue despite repeal of Sec. 553(a) [2].

1931969 Strvey, supra note 27 (responses of Department of Defense; FHA Commodity Stabilization Division, Department of Agriculture; Veterans' Administration; Small Business Administration; Office of Economic Opportunity). 
For example, the Department of Defense stated that "admittedly, the exemption is a broad one in which DoD would rely in issuance of any highly significant rule. . . . But the scope and volume of substantive rulemaking in the Department makes impracticable compliance with the unwieldy requirement for a 'finding and a brief statement of reasons' for the 'good cause." "194 In light of the fact that the statement of findings and reasons is only required in those cases in which the agency opts out of the usual procedures, and that it can be made for a whole class of rulemaking in the few instances where that can be justified on the basis of the special facts and circumstances discussed previously, this objection seems unsound. The burden involved here consists only in the agency setting down, in each situation where justified, the finding that public procedures are "impracticable, unnecessary, or contrary to the public interest," and a brief statement of the reasons why that is so. To some extent agencies should be doing that in any case-if they are in fact living up to their more general responsibilities to accord as much participation in rulemaking as possible, consistent with their other obligations. The burden, therefore, seems to be both of a kind and quantity that the agencies should be willing and able to bear in light of the attendant benefits.

A number of responses to the above question gave another reason why current exemptions contained in section 553(b)-(e) are inadequate substitutes for the subject exemptions of section 553 (a) (2). It is said that the scope of section $553(\mathrm{~b})(\mathrm{B})$ is unclear and uncertain. Reliance upon that exemption, therefore, would not clearly handle all the problems created by a repeal of section $553(\mathrm{a})(2)$; and it would probably result in much litigation as to the scope of the subsection (b) (B) exemption, causing undue delay in the execution of agency programs and the like. ${ }^{195}$ "Uncertainty about the scope of the exemption" and the fact that "such a finding [as is required by section $553(\mathrm{~b})(\mathrm{B})]$ is subject to challenge in the courts making uncertain the validity of any rule issued under this exemption" was noted. ${ }^{196}$ The Department of Agriculture's Rural Electrification Administration responded that the attendant possibilities for delay could be too easily utilized by one who wanted to obstruct one of the agency's programs. ${ }^{107}$

1941969 Survey, supra note 27.

1951969 Survey, supra note 27 (responses of Small Business Administration; REA, Department of Agriculture; Department of Commerce; Department of Defense). 1961969 Survey, supra note 27 (response of Department of Defense). 107

Just as the uncertainty of the scope of the other exemptions of Sec. 553 (b) -(e) invites litigations which could be used ... to obstruct the proper functioning of the agency ... so this good cause exemption could invite obstructive litigation. For example, Sec. 553(b) (B) requires a brief statement of the reasons for finding the notice and public procedure impracticable, 
It is true that the terms "good cause" and "impracticable, unnecessary, or contrary to the public interest" are not as precise as those which categorically exempt all rulemaking "relating to . . . public property, loans, grants, benefits, or contracts." The former terms are more difficult to apply. They involve some balancing because of the required special assessment of the facts in each case. Therefore, their application is not as obvious or indisputable as that of section 553 (a) (2).

Nevertheless, as previously noted, the language of section 553 (b) (B) can adequately deal with all of the problems created by a repeal of section 553(a)(2). It need not be as unclear as the opponents in this area claim. If section 553(a)(2) is repealed, a legislative history could also be created to clarify further the scope of section 553(b) (B). Moreover, litigation of the scope and proper applicability of "good cause" and "impracticable, unnecessary, or contrary to the public interest" is not apt to be any more endless or obstructive here than it is elsewhere. And in light of the above discussion, it is not in fact likely, in the overwhelming number of cases, to have any significant impact on the agencies' ability to perform their functions properly. Stare decisis should have a substantial effect within a brief time. It should also be noted that although wise and honest use of the section 553(b) (B) exemption by the relevant agencies will not forestall all litigation, it will forestall some.

In the end, however, it must still be admitted that there remains a real difference in clarity between the applicability of section 553 (a) (2) and section $553(\mathrm{~b})(\mathrm{B})$, and that some delays may be caused by litigation involving the latter. But these consequences are a price worth paying for the largely increased scope of the guarantee of public participation in rulemaking involved. After all, no showing has been made that they will have any serious ill effects in the mass of cases. If the fear really is that agencies will have to be careful in utilizing this qualified exemption, and that their hands will be tied by it to some extent, they are right. Similarly, if the fear is that in particularly close cases, the form of this exemption will cause agencies to utilize normal rulemaking procedures rather than risk possible litigation resulting in invalidation of the rule, ${ }^{198}$ that too is correct. Both of these

unnecessary or contrary to the public interest. The sufficiency of the agency's reasons might be attacked in a suit. Whether or not REA's action is ultimately sustained, the litigation in the meantime could defeat the purpose of the REA loan.

1969 Survey, supra note 27.

198 The Department of Agriculture's Farmers Home Administration feared that reliance solely upon the $\S 553$ (b) (B) exemption might discourage issuance of rules and needed changes in rules. See 1969 Survey, supra note 27. This consequence seems highly improbable. More likely is the consequence noted in the text above. 
results, however, are acceptable in light of the importance of the policy favoring public participation in rulemaking.

A number of very important agencies from the point of view of the section 553 (a) (2) exclusions admitted that the consequences resulting from a repeal of those exemptions could be handled by the remaining exemptions contained in section 553(b)-(e). The Department of Health, Education and Welfare noted that "the several specific exemptions contained in section 553(b)-(e) are sufficient to deal with the bulk of disadvantages that might be encountered if section 553 (a) (1)(2) were repealed." ${ }^{199}$ In light of those other specific exemptions, especially section 553 (b) (B), the Department of Transportation said that it "could live" with the repeal of the subsection (a) (2) exemptions under discussion and "would not object to [their] . . . repeal." 200 Similarly, the Department of Labor stated that the repeal of the exemptions relating to "public property, loans, grants, benefits, or contracts" would cause that agency "no undue hardship in view of the specific exemptions contained in section 553 (b) (B)." 201 It did express an exception, however, based on the assumption that its wage determinations problem might not be solved adequately by the latter exemption as it is now deemed to operate. Since the revised section 553 (b) (B) proposed here would enable the Department to solve this problem for that whole class of rulemaking by one operation, their doubts should be assuaged.

The same should be true of the Treasury Department. It admitted that

if all of Section (a) (1)-(2) was repealed, in the preparation of regulations which could not be published until announced by the Secretary, and in which speed and its requisite corollary, secrecy, are necessities, and advanced publicity and public participation opportunities, impossibilities, we recognize that we could resort to publication in our rule of a finding that notice and public procedures are contrary to the public interest.

But the Department was still concerned because it thought "an amendment of the nature indicated by this question does not take into account

1091969 Survey, supra note 27. See also the following responses to the 1969 Survey. The National Aeronautics and Space Administration stated: "On balance . NASA should not find itself greatly disadvantaged by a removal of $[\$ 553(\mathrm{a})]^{\circ} . "$ NASA went on to note that the exemptions presently contained in $\$ \$ 553(\mathrm{~b})-(\mathrm{e})$, especially $\$ 553(\mathrm{~b})(\mathrm{B})$ "should be adequate to prevent unreasonable, costly and empty exercises in rulemaking procedures from resulting." The Office of Economic Opportunity admitted that "the good cause exemption would of course serve as some protection against the undue formalism of the A.P.A. rulemaking procedures"; but it opposed repeal of $\S 553(\mathrm{a})(2)$.

2001969 Survey, supra note 27. The Department said, however, it would object to repeal of the "agency management and personnel" exemption of subsection (a) (2).

2011969 Survey, supra note 27. 
the continuing functions of the Treasury in its debt management operations." 202 As noted earlier, to the extent that usual procedures are in fact "impracticable, unnecessary, or contrary to the public interest" with respect to rulemaking involved in those functions, the Department has no cause for concern. However, to the extent that concern is a product of a desire for a broader exemption, the equities involved suggest it should not be honored.

None of the objections stated to an "impracticable, unnecessary, or contrary to the public interest" type solution to the problem under consideration has sufficient merit to discourage utilization of that approach. Consequently, a repeal of the section 553(a)(2) exemptions "relating to public property, loans, grants, benefits, or contracts" accompanied by a construction of section 553(b)(B) and section 553 (d) (3) along the lines suggested would be an excellent means by which to reconcile the conflicting societal interests involved. The exemptive language should not and need not be so broadly construed as to render it a meaningless limit on agency discretion forestalling adequate public participation in rulemaking, nor so narrowly construed as to render it an ineffective tool to deal with the real problems which admittedly might be faced by certain agencies if section 553 (a) (2) was repealed.

As noted earlier, this kind of qualified exemption will remove from the requirements of the rulemaking section virtually all of those situations now used to justify the across-the-board unqualified exceptions presently contained in section 553 (a) (2). Unlike the latter provision, however, the former has the advantage of excluding from the strictures of section 553(b)-(d) only those specific rulemaking situations where competing interests of a high order clearly outweigh the interests in public participation.

Furthermore, repeal of the section 553 (a) (2) exemptions in question will also be advantageous because the competing values involved will be more adequately accommodated in another way. Unlike the current unqualified exemption of subsection (a) (2) rulemaking from every provision of section 553, the solution proposed would only exempt particular instances of such rulemaking, where essential, from the specific subsections whose application would be unreasonable in those instances. So, even if prior public participation under section 553(b)(c) should be eliminated in a particular case of rulemaking, the agency will still be required, as section 553 (e) unqualifiedly demands, to give persons a right to petition for the issuance, amendment, or repeal of a rule. As noted previously, exemption from that requirement seems never to be justified. 
One final point with respect to the scope of the statutory reform proposed here deserves note. Rulemaking is defined by the APA as the process for formulating "agency statements of general or particular applicability and future effect designed to implement, interpret or prescribe law or policy . . . " 203 The procedures of section 553 are better adapted to dealing with rulemaking of general applicability than to dealing with rulemaking of particular applicability. Therefore, requiring adherence to the procedures of section 553 in the case of the latter class of subsection (a) (2) rulemaking may create larger burdens and smaller benefits than requiring adherence to those procedures for similar rulemaking of general applicability.

However, by using one of two exemptions, an agency can avoid the trouble of opening too wide the role of public participation in rulemaking of particular applicability. To the extent that it is more "impracticable, unnecessary, or contrary to the public interest" to follow normal procedures for subsection (a) (2) rulemaking of particular applicability than for such rulemaking of general applicability, the section 553(b) (B) and section 553(d) (3) exemptions can adequately handle the problem. As a result, one may expect greater resort to the section 553 (b) (B) and section 553(d) (3) exemptions for subsection (a) (2) rulemaking of particular applicability than for such rulemaking of general applicability.

Furthermore, section 553(b) permits agencies to avoid prior publication of notice in the Federal Register if "persons subject thereto are named and either personally served or otherwise have actual notice thereof in accordance with law." This means that after the repeal of section 553(a) (2), agencies will still not be required to publish advance notice of such rulemaking of particular applicability in the Federal Register if they only do what is fair in any case: give the persons "subject thereto" personal notice and "an opportunity to participate in the rulemaking through submission of written data, views, or arguments." This seems to be the result of a reconciliation of the language "persons subject thereto" in section 553(b) and "interested persons" in section 553 (c).

To continue the section 553(a) (2) exclusion as applied to rulemaking of particular applicability would mean that rules of this sort would be subject neither to the statutory provisions governing rulemaking procedure nor to the statutory provisions governing adjudicatory procedure. This result would be most unfortunate. Some clear statutory protection ought to be given affected parties in situations where agencies make rules of particular applicability relating to "public

2035 U.S.C. §551(4) (Supp. IV, 1969) (emphasis ađded). 
property, loans, grants, benefits, or contracts." The particular persons involved have much at stake, and the public interest in assuring that the official decision-makers are adequately informed in such cases is great, even though not as great as in cases of rulemaking of general applicability. Consequently, until that time when the general definition of "rule" used in the APA is changed so that "rulemaking" of particular applicability is treated as adjudication, the procedural protections of section 553 should be made applicable to all subsection (a) (2) regulation formation. The various exemptions now contained in section 553 will adequately deal with any special problems that arise from application of that provision to such rulemaking of particular applicability.

\section{ConcLusion}

Serious proposals for the elimination of the section 553(a)(2) exemptions for rulemaking relating to "public property, loans, grants, benefits, or contracts" have been made since at least 1955. The Task Force Report on Legal Services and Procedure of the Hoover Commission noted in that year that

many rules governing proprietary matters, such as procedures respecting public property, loans [grants], benefits, and contracts, are of vital importance to the members of the public affected by them. Such rules often have a direct bearing upon private interests, and participation in the rulemaking process by those affected is appropriate and to be desired.204

The Task Force concluded that "proprietary functions may . . . be effectively executed by agencies with public participation in the rulemaking process" and, therefore, what is now section 553 (a) (2) should be repealed. ${ }^{205}$ It was convinced that "the requirement of public participation [in those cases] does not subject departments and agencies to an unreasonable procedural burden." ${ }^{206}$ Since that time several bills have sought to accomplish the same result: elimination of section 553 (a) (2) as it is presently constituted.

This study demonstrates that the 1955 Task Force Report of the Hoover Commission and the bills since introduced into Congress were correct. The unqualified exemptions from section 553 for all rulemaking relating to "public property, loans, grants, benefits, or contracts" should be repealed. The reasons advanced to justify those exemptions are not sufficient. At most, those justifications dictate the need for a more narrowly tailored exemption from usual rulemaking

204 TASK FORCE REPORT, supra note 6, at 158-59.

205 Id. 159.

206 Id. 160. 
proceedings than is currently found in section 553 (a) (2). The existing "impracticable, unnecessary, or contrary to the public interest" provision found in section 553 (b) (B) and the "good cause" exemption found in section 553 (d) (3) provide such an exclusion from the requirements of section 553(b)-(d). They would work an adequate accommodation of the competing interests involved, carefully balancing the need for public participation against the need for effective, efficient, expeditious, and inexpensive government administration. And an exemption from the right to petition conferred by section 553(e) seems no more necessary or justifiable for subsection (a) (2) rulemaking than for rulemaking already covered by section 553 .

The solution proposed here to the difficulties arising from the repeal of section 553 (a) (2) is bound to put some additional burden on the agencies who will have to implement it. But the burden involved in agency use of the section 553(b) (B) and section 553(d) (3) exemptions is not likely to be very large. Furthermore, any administrative burden that is in fact likely to result from the proposed solution would seem clearly outweighed by the benefits obtained. Repeal of section 553 (a) (2) will, after all, guarantee increased public participation in rulemaking of the kinds currently excluded from usual procedures by that provision.

A discouraging discovery made in the course of this study has been that a number of agencies opposing modification of section 553(a) (2) do not seem to have restudied their position carefully and seriously during the last few years. Statements opposing repeal of these exemptions that were prepared as long as five, ten, or even thirteen years ago are still used by some agencies as the principal basis for articulating their current position on this subject. The language of a few such statements has sometimes not even been modified to reflect subsequent changes in the law, or obvious changes in circumstances, when they were reissued in light of a new inquiry on this subject. It is hoped that the present study can at the very least provoke those agencies who have opposed modification of section 553(a)(2) into conducting a serious and careful reconsideration of their position on the question. That reconsideration should result in this realization: repeal of the exemptions for rulemaking relating to "public property, loans, grants, benefits, or contracts" need not seriously disadvantage them in light of existing exemptions contained in other portions of section 553 .

In conclusion, it should be reiterated that the proposal made in this study would only affect the section 553(a)(2) exemptions for rulemaking relating to "public property, loans, grants, benefits, or contracts." The current proposal would not affect, in any way, the 
existing section 553 (a)(1) exemption for rulemaking involving a "military or foreign affairs function," or the existing section 553 (a) (2) exemption for rulemaking relating to "agency management or personnel." Similarly undisturbed would be the exemption from section 553(b)-(d) of all "interpretative rules" and "statements of policy" found in section 553(b) (A) and section 553(d)(2). The above exemptions, when combined with section $553(\mathrm{~b})(\mathrm{B})$ and the "good cause" exemption found in section 553(d) (3), should provide fully adequate leeway for all agencies to meet their responsibilities properly, even after the repeal of section 553 (a) (2). 


\section{APPENDIX}

The following recommendation was made by the Administrative Conference of the United States at its Third Plenary Session, October 21-22, 1969, in Washington, D. C.

\section{Recommendation No. 16-Elimination of Certain Exemptions From the APA Rulemaking Requirements}

\section{RECOMMENDATION}

In order to assure that Federal agencies will have the benefit of the information and opinion that can be supplied by persons whom regulations will affect, the Administrative Procedure Act requires that the public must have opportunity to participate in rulemaking proceedings. The procedures to assure this opportunity are not required by law, however, when rules are promulgated in relation to "public property, loans, grants, benefits, or contracts." 'These types of rules may nevertheless bear heavily upon non-governmental interests. Exempting them from generally applicable procedural requirements is unwise. The present law should therefore be amended to discontinue the exemptions to strengthen procedures that will make for fair, informed exercise of rulemaking authority in these as in other areas.

Removing these statutory exemptions would not diminish the power of the agencies to omit the prescribed rulemaking procedures whenever their observances were found to be impracticable, unnecessary, or contrary to the public interest. A finding to that effect can be made, and published in the Federal Register, as to an entire subject matter concerning which rules may be promulgated. Each finding of this type should be no broader than essential and should include a statement of underlying reasons rather than a merely conclusory recital.

Wholly without statutory amendment, agencies already have the authority to utilize the generally applicable procedural methods even when formulating rules of the exempt types now under discussion. They are urged to utilize their existing powers to employ the rulemaking procedures provided by the Administrative Procedure Act, whenever appropriate, without awaiting a legislative command to do so. 